\title{
Vegetable oil as fat replacer inhibits formation of heterocyclic amines and 2 polycyclic aromatic hydrocarbons in reduced fat pork patties
}

Article

Accepted Version

Creative Commons: Attribution-Noncommercial-No Derivative Works 4.0

Lu, F., Kuhnle, G. K. and Cheng, Q. (2017) Vegetable oil as fat replacer inhibits formation of heterocyclic amines and 2 polycyclic aromatic hydrocarbons in reduced fat pork patties. Food Control, 81. pp. 113-125. ISSN 0956-7135 doi: https://doi.org/10.1016/j.foodcont.2017.05.043 Available at https://centaur.reading.ac.uk/70536/

It is advisable to refer to the publisher's version if you intend to cite from the work. See Guidance on citing.

Published version at: http://ac.els-cdn.com/S0956713517302852/1-s2.0-S0956713517302852-main.pdf? _tid=f5d9a0cc-42f6-11e7-aa61-00000aab0f6c\&acdnat=1495901591_36523bfad4dcbb6a29079af52fcc6489 To link to this article DOI: http://dx.doi.org/10.1016/j.foodcont.2017.05.043

Publisher: Elsevier

All outputs in CentAUR are protected by Intellectual Property Rights law, including copyright law. Copyright and IPR is retained by the creators or other copyright holders. Terms and conditions for use of this material are defined in the End User Agreement. 


\section{CentAUR}

Central Archive at the University of Reading

Reading's research outputs online 


\section{Accepted Manuscript}

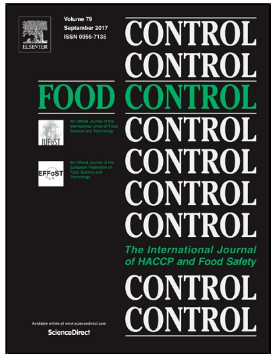

Fei Lu, Gunter K. Kuhnle, Qiaofen Cheng

Vegetable oil as fat replacer inhibits formation of heterocyclic amines and polycyclic aromatic hydrocarbons in reduced fat pork patties

PII:

S0956-7135(17)30285-2

DOI:

10.1016/j.foodcont.2017.05.043

Reference:

JFCO 5649

To appear in:

Food Control

Received Date:

05 March 2017

Revised Date:

25 May 2017

Accepted Date:

26 May 2017

Please cite this article as: Fei Lu, Gunter K. Kuhnle, Qiaofen Cheng, Vegetable oil as fat replacer inhibits formation of heterocyclic amines and polycyclic aromatic hydrocarbons in reduced fat pork patties, Food Control (2017), doi: 10.1016/j.foodcont.2017.05.043

This is a PDF file of an unedited manuscript that has been accepted for publication. As a service to our customers we are providing this early version of the manuscript. The manuscript will undergo copyediting, typesetting, and review of the resulting proof before it is published in its final form. Please note that during the production process errors may be discovered which could affect the content, and all legal disclaimers that apply to the journal pertain. 
1 Vegetable oil as fat replacer inhibits formation of heterocyclic amines and

2 polycyclic aromatic hydrocarbons in reduced fat pork patties

Fei Lu, Gunter K. Kuhnle and Qiaofen Cheng*

Department of Food and Nutritional Sciences, University of Reading, Whiteknights, PO Box 226, Reading RG6 6AP, UK

*Corresponding author - Email: q.cheng@reading.ac.uk

\section{Abstract}

Formation of heterocyclic amines (HCAs) and polycyclic aromatic hydrocarbons (PAHs) was examined to evaluate the impact of using vegetable oil as fat replacement on carcinogen formation in meat product. Pork patties were formulated with $40 \%$ fat replacement by olive oil, sunflower oil or grape seed oil, respectively and cooked at $180^{\circ} \mathrm{C}$ or $220^{\circ} \mathrm{C}$. Control patties contained the highest amount of HCAs compared with all other patties at both temperatures. Olive oil and sunflower oil replacement completely inhibited formation of MelQ (2-amino-3, 4methylimidazo[4,5-f]quinoline), while grape seed oil completely inhibited MelQx (2amino-3,8-dimethylimidazo[4,5-f]quinoxaline),

4,8-DiMelQx

(2-amino-3,4,8trimethylimidazo[4,5-f]quinoxaline) and PhIP (2-amino-1-methyl-6-phenylimidazo[4,5b]pyridine) in patties. Grape seed oil achieved the highest inhibition capacity compared with sunflower oil and olive oil. HCAs increased significantly with cooking temperature $(p<0.05)$, but no difference was observed in total PAHs for patties cooked at different temperature $(p>0.05)$. In conclusion, fat replacement with sunflower oil, olive oil or grape seed oil in pork patties could reduce the formation of HCAs without compromising eating quality. 
Key words: Antioxidants; Fat modification; Maillard reactions; Oxidation.

\section{Chemical compounds studied in this article:}

2-amino-3-methylimidazo[4,5-f]quinoline (PubChem CID: 53462); 2-Amino-3,4dimethylimidazo[4,5-f]quinoline (PubChem CID: 62274); 2-Amino-3,8dimethylimidazo[4,5-f]quinoxaline (PubChem CID: 62275); 2-amino-3,4,8trimethylimidazo[4,5-f]quinoxaline (PubChem CID: 104739); 2-Amino-1-methyl-6phenylimidazo[4,5-b]pyridine (PubChem CID: 1530); Benzo[a]pyrene (PubChem CID: 2336); Benz[a]anthracene (PubChem CID: 5954)

\section{Introduction}

Fat plays an important role in the human diet. It not only creates a unique sensation of food, but also helps maintain health. The consumption of pork in the world has dramatically increased from 18 to 110 million tons per year (1950-2010) (Brown, 2013). Research found that increased saturated fatty acid intake could elevate the risk of cardiovascular disease, but monounsaturated fatty acids (MUFA) and polyunsaturated fatty acids (PUFA) could reduce the risk and maintain cardiovascular health (McAfee et al., 2010; Sadler, 2014). Therefore, changing fatty acids profile of meat products by replacing saturated fatty acids with unsaturated fatty acids has attracted lots of attention in both academic research and meat processors. Adding olive oil could dramatically increase the percentage of MUFA in final products, whereas sunflower oil and grape seed oil could greatly raise the level of PUFA in fat replaced meat products (Gunstone, 2002; Matthäus, 2008). Rodríguez-Carpena et al. (2012) successfully replaced $50 \%$ fat with avocado, sunflower and olive oil in cooked pork patties and reported that avocado and olive oil could even offer better aroma to the final products than control ones. Vural and 
Javidipour (2002) successfully substituted beef fat in Frankfurters with the mixture of interesterified palm, cottonseed, and olive oil without changing physical parameters and total sensory scores. Choi et al. (2010) used pre-emulsified grape seed oil and $2 \%$ rice bran fibre to develop pork batters with $50 \%$ fat replacement and reported that the fat-reduced pork batters could achieve the comparable eating quality with control samples. Domínguez, Agregán, Gonçalves, and Lorenzo (2016) replaced 100\% pork back fat with olive oil in pork pâté, which significantly increase the content of tocopherol and MUFA in cooked products without altering physio-chemical properties. Domínguez, Pateiro, Agregán, and Lorenzo (2017) and Lorenzo, Munekata, Pateiro, Campagnol, and Domínguez (2016) replaced 25\%-75\% backfat with olive oil, microencapsulated fish oil and the mixture of fish oil and olive oil, which significantly increased the percentage of PUFA in frankfurter type sausage and Spanish salchichón. These results indicate that vegetable oil could be used successfully to replace fat partially or completely to offer products comparable eating quality with healthier fatty acids profile, i.e. high level of MUFA and PUFA.

However, unsaturated fatty acids in vegetable oils may pose risk in domestic cooking due to their oxidation and decomposition at high temperature. For example, linoleic acid was found associated with the formation of potentially toxic compounds, such as free radicals, aldehydes and ketones (Guillén \& Uriarte, 2012a; Katragadda et al., 2010). These reactive oxygen species (ROS) initiated by unsaturated fatty acids peroxidation could induce the decomposition of Amadori compounds and generate 1- and 3- deoxysone that are intermediates for Strecker aldehydes, pyrazines and pyridines in Maillard reaction. Consequently, it might promote the formation of heterocyclic amines (HCAs) (Morello, Shahidi \& Ho, 2002; Turesky, 2010; Zamora \& Hidalgo, 2007). Effect of fatty acids/oils on the formation of HCAs has been 
documented in previous research. Johansson et al. (1995) reported that the higher level of MelQx and DiMelQx were found in burgers fried in rapeseed oil containing high level of oleic acid with high peroxides values, compared with butter, margarine and sunflower oil. Zamora et al. (2012) stated that both primary and secondary lipid oxidation products, hydroperoxides, such as methyl 13-hydroperoxyoctadeca-9,11dienoate and alkenals could accelerate the formation of PhIP in chemical model system. Some hydroperoxides generated from the decomposition of the unsaturated hydrocarbons during heating, such as linolenate acid can also undertake aromatization and de-hydrocyclization, further cleave into benzaldehydes and other benzene ring-containing compounds, which are precursors of polycyclic aromatic hydrocarbons (PAHs) (Chen \& Chen, 2001; Lorenzo et al., 2011; Lorenzo, Purriños, Fontán, \& Franco, 2010; Singh, Varshney \& Agarwal, 2016).

HCAs, PAHs and N-nitrous compounds are well-known carcinogens which were detected in processed meat products (Hasnol, Jinap \& Sanny, 2014; Jinap et al., 2013; Liao et al., 2010; Oz \& Kaya, 2010; Salmon, Knize \& Felton, 1997). HCAs are mainly formed with the presence of free amino acids, carbohydrates and creatine under high cooking temperature (Rahman et al., 2014). IARC (1993) classified the following 5 aminoimidazoarenes (AIAs) compounds as human carcinogens, including 2-amino-3-methylimidazo[4,5-f]quinoline $\quad(I Q), \quad$ 2-amino-3,4-methylimidazo[4,5f]quinoline (MeIQ), 2-amino-3,8-dimethylimidazo[4,5-f]quinoxaline (MelQx), 2-amino3,4,8-trimethylimidazo[4,5-f]quinoxaline (4, 8-DiMelQx) and 2-amino-1-methyl-6phenylimidazo[4,5-b]pyridine (PhIP). PAHs are hydrocarbons that contain two or more benzene rings, such as pyrene, anthracene and naphthalene. They can be formed through incomplete combustion or pyrolysis of organic components, including fat, protein and carbohydrates at the temperature over $200^{\circ} \mathrm{C}$. Grilling, roasting and 
smoking meat products likely contain high level of PAHs (Alomirah et al., 2011). Benz[a]anthracene $(\mathrm{BaA})$ and benzo[a]pyrene $(\mathrm{BaP})$ are the most potent carcinogenic PAHs in processed meat products (PHE, 2008). The metabolite of BaP, BaP-7,8-diol-9,10-epoxide, has been reported with the highest tumour-inducing activity due to causing DNA adducts (Purcaro, Moret \& Conte, 2013).

Vegetable oils contain various antioxidants such as vitamin E, ß-carotenes and phenolic compounds (Ramírez-Anaya et al., 2015). These antioxidants have been characterized as free radical scavengers during cooking, which might inhibit the formation of carcinogens (Janoszka, 2011; Wong, Cheng \& Wang, 2012). Cheng, Chen and Wang (2007) reported that marinating beef patties with phenolic compounds such as epicatechin gallate, rosmarinic acids and carnosic acid could significantly reduce HCAs by $24 \%-70 \%$ in final cooked products. Balogh et al. (2000) found that HCAs (IQ, MelQ, MelQx, DiMelQx and PhIP) were inhibited by $45 \%-75 \%$ when sprayed $1 \%$ vitamin $E(w / w)$ on the surface of beef patties before frying. Therefore, in the concern of the carcinogen level in processed meat products, replacing saturated fat with vegetable oils rich in unsaturated fatty acids needs to be justified. Thus, the objectives of this study were to (1) explore the effect of partially replacing pork back fat with sunflower oil, olive oil and grape seed oil on the formation of HCAs and PAHs; (2) examine the effect of different cooking temperatures on the formation of carcinogens in fat reduced pork patties.

\section{Material and methods}

\subsection{Materials}

Three batches of lean pork leg and pork back fat with $40.3 \%$ SFA, $43.4 \%$ MUFA and 10.0\% PUFA (McCance \& Widdowson, 2002) were purchased from Jennings Caversham (Reading, UK) at different time point to consider the batch effect. 
123

124

125

126

127

128

129

130

131

132

133

134

135

136

137

138

139

140

141

142

143

144

145

146

147

Excess visible fat on pork legs was trimmed, then minced by a Kenwood Food processor (Chef Titanium KM010, 4.6, Kenwood Limited) and vacuum packed separately. Raw materials were stored at $-18{ }^{\circ} \mathrm{C}$ and defrosted $24 \mathrm{~h}$ at $4{ }^{\circ} \mathrm{C}$ before use. Commercial grape seed oil (Waitrose ${ }^{\odot}$, produced in Italy) with $12.4 \%$ SFA, 20.2\% MUFA, $68.2 \%$ PUFA, 10-15mg tocopherols and 5.9-11.5mg/100g polyphenols (Bail, Stuebiger, Krist, Unterweger, \& Buchbauer, 2008), sunflower oil (Morrisons ${ }^{\odot}$, produced in UK) with $14.3 \%$ SFA, 20.5\% MUFA, $63.3 \%$ PUFA and 50mg tocopherols (McCance \& Widdowson, 2002) and refined olive oil (Filippo ${ }^{\odot}$, phenols were removed by industrial process, produced in Italy) with $14.3 \%$ SFA, $73.0 \%$ MUFA, $8.2 \%$ PUFA and 100-300mg tocopherols (McCance \& Widdowson, 2002) were purchased from local supermarket (Reading, UK). Oils were kept in refrigerator $\left(4^{\circ} \mathrm{C}\right)$ before making patties and further analysis.

The standards IQ (2-amino-3-methyl-imidazo [4,5-f] quinoline), MeIQ (2-amino-3,4dimethyl-imidazo $[4,5-f] \quad$ quinoline), $\quad$ MelQx (2-amino-3,8-dimthylimidazo [4,5f]quinoxaline), 4,8-DiMelQx (2-amino-3,4,8-trimethyl-imidazo [4,5-f] quinoxaline), PhIP (2-amino-1-methyl-6-phenylimidazo [4,5-b] pyridine, BaA (Benz[a]anthracene) and $\mathrm{BaP}$ (benzo[a]pyrene) were purchased from Toronto Research Chemicals (Toronto, Canada). Ammonium acetate, triethylamine, acetonitrile (HPLC grade), bovine serum albumin (BSA), dinitrophenylhydrazine (DNPH), ethyl acetate $99.5 \%$ $0.9000 \mathrm{~g} / \mathrm{ml}, 6 \mathrm{M}$ guanidine $\mathrm{HCl}(\mathrm{pH} 6.5)$, hydrochloric acid solution $0.1 \mathrm{M}$, methanol (HPLC grade), HPLC grade water, sodium hydroxide 1M, perchloric acid (99.8\%), sodium phosphate buffer ( $\mathrm{pH}$ 6.5), thiobarbituric acid (TBA), and trichloroacetic acid (TCA) were purchased from Fisher Scientific (Loughborough, UK). 2,2-Azobis(2methylpropionamidine) dihydrochloride granular 97\% (ABAP), 2,2-Azino-bis(3ethylbenzothiazoline-6-sulfonic acid) diammonium salt (ABTS), ( \pm )-6-Hydroxy- 
2,5,7,8-tetramethylchromane-2-carboxylic acid (Trolox), phosphate buffer solution $0.1 \mathrm{M}$ and phosphoric acid were purchased from Sigma-Aldrich (Gillingham, UK). The solid-phase extraction Extrelut NT 20 columns and diatomaceous earth refill material were purchased from Merck (Darmstadt, Germany). Bond Elut propylsulfonic acid (PRS) cartridges (100 mg, $10 \mathrm{ml}), \mathrm{C}-18$ cartridges $(7 \mathrm{ml})$ were purchased from VWR Inc (Lutterworth, UK).

\subsection{Procedures for preparing and cooking pork patties}

The formulation of control patties (as shown in Table 2) included $700 \mathrm{~g}$ lean pork mince, $180 \mathrm{~g}$ distill water, $100 \mathrm{~g}$ pork back fat and $20 \mathrm{~g}$ salt per kilogram. For the fat partially replaced patties, $40 \%$ of pork back fat was replaced with sunflower oil, olive oil or grape seed oil respectively. Overall, there were 4 types of pork patties prepared in this study, i.e. control (100\% back fat, C patties), sunflower oil patties (S patties), olive oil patties ( $O$ patties) and grape seed oil patties (G patties). All ingredients were homogenized at 5000rpm for $5 \mathrm{~min}$ in the Kenwood Food processor to reach a uniform emulsion. Each patty was weighed $100 \mathrm{~g}$, shaped in a foil cup (9.0 cm diameter * $2.5 \mathrm{~cm}$ height) for standardization.

Patties were cooked in an air-forced oven at either $180^{\circ} \mathrm{C}$ or $220^{\circ} \mathrm{C}$. Cooking was terminated when core temperature of patties reached to $73^{\circ} \mathrm{C}$. After cooking, pork patties were covered by foil and chilled in cold room at $4{ }^{\circ} \mathrm{C}$ for 24 hours. Physical properties including texture and colour were measured on the following day of cooling. While part of samples were homogenized and stored in $-18^{\circ} \mathrm{C}$ for further chemical analysis. Cooking loss was determined according to the equation: Cooking loss $(\%)=\left(W_{r}-W_{c}\right) / W_{r}$, where $W_{r}$ was the weight of raw pork patties, and $W_{c}$ was 
weight of cooked pork patties. All the treatments were replicated three times. For each replicate, 8 patties were made for each treatment.

\subsection{Composition analysis: $\mathrm{pH}$, moisture, fat and protein content}

$\mathrm{pH}$ was measured by inserting a $\mathrm{pH}$ meter (68X243601, Oakton Instruments, USA) into the mixture by blending $5 \mathrm{~g}$ meat sample with $45 \mathrm{ml}$ distill water (Puangsombat et al., 2011). The moisture content was determined by drying $3 \mathrm{~g}$ meat samples in an oven at $100^{\circ} \mathrm{C}$ for 24 hours according to AOAC methods (Horwitz \& Latimer, 2005). The fat content was determined by drying sample in an oven for 4 hours firstly then using Soxhlet extraction system. The protein content was determined using the Kjeldahl method (Horwitz \& Latimer, 2005).

\subsection{Lipid/protein oxidation and antioxidant capacity}

\subsubsection{Lipid oxidation--Thiobarbituric acid-reactive substances (TBARS) value}

The degree of lipid oxidation in samples was expressed by TBARS values, which were determined by the method reported by Rodríguez-Carpena et al. (2012). $5 \mathrm{~g}$ well blended pork patty was homogenized with $15 \mathrm{ml}$ perchloric acid $(3.86 \%)$ and $0.5 \mathrm{ml} \mathrm{BHT}(4.2 \%$ in ethanol) in a beaker, which was immersed in an ice bath to minimize oxidative reactions in samples during extraction. The mixture was then filtered and centrifuged at $3000 \mathrm{rpm}$ for $4 \mathrm{~min}, 2 \mathrm{ml}$ supernatant was mixed with $2 \mathrm{ml}$ thiobarbituric acid $(0.02 \mathrm{M})$ in test tube. The test tubes were then placed in a boiling water bath $\left(100^{\circ} \mathrm{C}\right)$ for $45 \mathrm{~min}$. After cooling, the absorbance was measured at 532nm using a spectrophotometer (6315, Bibby Scientific Ltd, UK). The standard curve was prepared using 1,1,3,3-tetraethoxypropane (TEP) in 3.86\% perchloric acid with the concentration of $0,0.5,1.0,2.5,5.0$ and $10.0 \mu \mathrm{M}$. 


\subsubsection{Total protein carbonyl value (Protein oxidation)}

The degree of protein oxidation can be evaluated by calculating the total carbonyl value according to the method described by Rodríguez-Carpena et al. (2012). $1 \mathrm{~g}$ of well blended pork patties was homogenized at 1:10 (w/v) in $20 \mathrm{mM}$ sodium phosphate buffer containing $0.6 \mathrm{M} \mathrm{NaCl}(\mathrm{pH} \mathrm{6.5)}$ for $30 \mathrm{~s}$. Two equal aliquots of $0.2 \mathrm{ml}$ mixture were then dispensed in $2 \mathrm{ml}$ eppendorf tubes, respectively. $1 \mathrm{ml}$ cold trichloroacetic acid (TCA) (10\%, w/w) was added into tubes and centrifuged for $5 \mathrm{~min}$ at $5000 \mathrm{rpm}$. One pellet was mixed with $1 \mathrm{ml} 2 \mathrm{M} \mathrm{HCl}$ in order to measure protein concentration, while the other pellet was mixed with $1 \mathrm{ml}$ of $0.2 \%(\mathrm{w} / \mathrm{v})$ dinitrophenylhydrazine (DNPH) in $2 \mathrm{M} \mathrm{HCl}$ in order to measure carbonyl concentration. Both tubes were incubated for $1 \mathrm{~h}$ at room temperature. Subsequently, $1 \mathrm{ml} 10 \%$ TCA was added into tubes and pellets were washed twice with $1 \mathrm{ml}$ ethanol: ethyl acetate $(1: 1, v / v)$ to remove excess of $\mathrm{DNPH}$. The pellets were then mixed with $1 \mathrm{ml}$ of $20 \mathrm{mM}$ sodium phosphate buffer containing $6 \mathrm{M}$ guanidine $\mathrm{HCl}$ (pH 6.5), stirred and centrifuged for $2 \mathrm{~min}$ at $5000 \mathrm{rpm}$ to remove insoluble fragments. Protein concentration was calculated from absorption at $280 \mathrm{~nm}$ using BSA as standard. The amount of carbonyls was expressed as nmol of carbonyl per mg of protein using an absorption coefficient of $21.0 \mathrm{nM}^{-1} \mathrm{~cm}^{-1}$ for absorbance at $370 \mathrm{~nm}$ for DNPH.

\subsubsection{Trolox equivalent antioxidant capacity (TEAC) of vegetable oil/ back fat}

TEAC was used to evaluate the total antioxidant capacity of vegetable oils and pork back fat. The measuring procedures were based on the method reported by van den Berg et al. (1999). An ABTS radical solution was prepared by mixing $2.5 \mathrm{mM}$ ABAP with $20 \mathrm{mM} \mathrm{ABTS}{ }^{2-}$ stock solution in $100 \mathrm{mM}$ phosphate buffer $(\mathrm{pH} 7.4)$, which 
contained $150 \mathrm{mM} \mathrm{NaCl}$. The solution was covered with foil and heated at $60^{\circ} \mathrm{C}$ for $12 \mathrm{~min}$, then cooled down to room temperature. $40 \mu \mathrm{l}$ of the sample solution was mixed with $1960 \mu \mathrm{l}$ of the freshly prepared ABTS/ABAP solution. Difference of absorbance at $734 \mathrm{~nm}$ in $6 \mathrm{~min}$ was recorded. A calibration curve was made by measuring the difference of absorbance in $6 \mathrm{~min}$ for Trolox at the concentration of 0 , $0.5,1.0,2.5,5.0,7.5$ and $10.0 \mu \mathrm{M}$. The TEAC of vegetable oil or back fat was presented on a molar basis to Trolox ( $\mu \mathrm{mol}$ Trolox/100g).

\subsection{Analysis of HCAs}

HCAs extraction and purification were following the procedures reported by Puangsombat et al. (2011). To minimize the variation and bias due to the unevenly distribution of sauce on the surface of meat, all samples were blended well with sauce before measuring. $3 \mathrm{~g}$ ground meat sample was mixed with $12 \mathrm{ml} 1 \mathrm{M}$ sodium hydroxide firstly, then the mixture was transferred into an Extrelut 20 column with $17 \mathrm{~g}$ diatomaceous earth. The HCAs were eluted by $60 \mathrm{ml}$ ethyl acetate in Extrelut column, and transferred into PRS cartridge which was pre-conditioned with $7 \mathrm{ml}$ ethyl acetate. A PRS cartridge was then washed with $6 \mathrm{ml} 0.1 \mathrm{M} \mathrm{HCl}, 15 \mathrm{ml}$ methanol/0.1M $\mathrm{HCl}(45 / 55, \mathrm{v} / \mathrm{v})$ and $2 \mathrm{ml}$ pure water to remove interferences from the PRS cartridge. The HCAs were then eluted by $20 \mathrm{ml} 0.5 \mathrm{M}$ ammonium acetate $(\mathrm{pH} 8.5)$ from the PRS cartridge and transferred into a C-18 cartridge that was conditioned with $5 \mathrm{ml}$ methanol and $5 \mathrm{ml}$ pure water. Finally, HCAs were eluted with $1 \mathrm{ml}$ methanol/ammonium hydroxide $(9 / 1, \mathrm{v} / \mathrm{v})$ from $\mathrm{C}-18$ cartridge into $2 \mathrm{ml}$ vial, followed by drying the mixture under nitrogen stream for $1.5 \mathrm{~h}$ at room temperature. The residue in the vial was dissolved with $1 \mathrm{ml}$ methanol and submitted for HPLC analysis. $1 \mathrm{ml}$ of mixtures containing 5 standard compounds $(I Q, M e I Q$, MelQx, 4, 8-DiMelQx 
and $\mathrm{PhIP})(5 \mathrm{ng} / \mathrm{ml})$ was spiked into samples before extraction for measuring the recovery rate. Three replicates were carried out for each sample.

IQ, MelQ, MelQx, 4, 8-DiMelQx and PhIP were analysed using HPLC (HP1635 Series, Agilent ChemStation, Agilent Technologies, Kidlington, UK) connected with a diode array UV detector (RF 2000). The HCAs were separated gradually by a reversed-phase Luna $5 \mathrm{u}$ C18 column $(250 \times 4.60 \mathrm{~mm}, 5 \mu \mathrm{m}, 100 \mathrm{~A}$, Product No: 00G-4252-E0, Phenomenex, UK). Mobile phase A was $0.01 \mathrm{M}$ triethylamine (adjusted pH 3.6 with phosphoric acid) and phase B was acetonitrile (>99\%, HPLC grade). The solvent contained $95 \% \mathrm{~A}$ and $5 \% \mathrm{~B}$ at beginning, then linearly changed to $75 \% \mathrm{~A}$ and $25 \% \mathrm{~B}$ within $30 \mathrm{~min}$ at flow rate $1.0 \mathrm{ml} / \mathrm{min}$. The temperature of column was $40^{\circ} \mathrm{C}$. The UV detector was set at $252 \mathrm{~nm}$ (Puangsombat et al., 2011).

\subsection{Analysis of PAHs}

$5 \mathrm{~g}$ meat sample was homogenised with $15 \mathrm{ml} 1 \mathrm{M} \mathrm{NaOH}$ for $1 \mathrm{~h}$. The homogenized sample was then mixed with $17 \mathrm{~g}$ diatomaceous earth and loaded in an Extrelut 20 column. Elution of PAHs started from Extrelut column, and was followed by propyl sulphonic acid (PRS) cartridges with $60 \mathrm{ml}$ of $\mathrm{CH}_{2} \mathrm{Cl}_{2}$ containing $5 \%$ toluene. The dichloromethane solution was then evaporated to small amount $(0.5-1 \mathrm{ml})$ and the rest of the solvent was dried under a nitrogen stream. The residue was re-dissolved in $1 \mathrm{ml} \mathrm{n}$-hexane and transferred to the top of a glass column packed with silica-gel $(10 \mathrm{~g})$. PAHs were then eluted by $25 \mathrm{ml}$ of $\mathrm{n}$-hexane and $60 \mathrm{ml}$ of $60: 40(\mathrm{v} / \mathrm{v}) \mathrm{n}$ hexane- $-\mathrm{CH}_{2} \mathrm{Cl}_{2}$ mixtures. After evaporation to dryness the residues were dissolved in acetonitrile (spiked and unspiked samples) before the HPLC analysis (Janoszka, 2011). 50ng of 2 standard mixtures ( $\mathrm{BaA}$ and $\mathrm{BaP}$ ) was spiked for measuring the recovery rate. 
$266 \mathrm{BaA}$ and BaP were analysed using HPLC (HP1635 Series, Agilent ChemStation,

267 Agilent Technologies, Kidlington, UK) connected with a fluorescence detector. 268 Mixture of $84 \%$ acetonitrile (>99\%, HPLC grade) and $16 \%$ water (HPLC grade) were 269 used as a mobile phase under isocratic conditions. The separations were performed 270 at $40^{\circ} \mathrm{C}$ under isocratic conditions with flow rate $1.0 \mathrm{ml} / \mathrm{min}$. The fluorescence 271 detection was performed by applying the following excitation (Ex)/emission (Em) wavelength program: $280 / 410 \mathrm{~nm}$ from 0 to $8.50 \mathrm{~min}(\mathrm{BaA}), 376 / 410 \mathrm{~nm}$ from 8.50 to $15 \min (\mathrm{BaP})$ (Janoszka, 2011).

\subsection{Recovery rate of HCAs and PAHs}

The 5 standard HCA (IQ, MelQ, MelQx, 4, 8-DiMelQx and PhIP) and 2 PAHs (BaA and $\mathrm{BaP}$ ) compounds were identified through the retention time of the peaks, and the quantity of each individual compound was determined according to the standard calibration curves, which was established by the standard solution at $0.5 \mathrm{ng} / \mathrm{ml}$, 5ng/ml and 50ng/ml. Limit of detection (LOD) for IQ, MelQ, MelQx, 4, 8-DiMelQx, PhIP, BaA and BaP were for 0.02 ng/g, $0.01 \mathrm{ng} / \mathrm{g}, 0.02 \mathrm{ng} / \mathrm{g}, 0.05 \mathrm{ng} / \mathrm{g}, 0.03 \mathrm{ng} / \mathrm{g}$, $0.07 \mathrm{ng} / \mathrm{g}$ and $0.06 \mathrm{ng} / \mathrm{g}$. The average recoveries of these $5 \mathrm{HCAs}$ based on triplicates were $60.01 \%$ for IQ, 61.76\% for MelQ, 53.64\% for MelQx, 60.57\% for 4,8DiMelQx and 55.98\% for PhIP. Results were comparable with several published data (Gibis, Kruwinnus \& Weiss, 2015; Messner \& Murkovic, 2004; Oz \& Cakmak, 2016; Yao et al., 2013). The recovery rate for $\mathrm{BaA}$ and $\mathrm{BaP}$ was 54.37 and $49.54 \%$ respectively, which was comparable with published results of $50 \%-115 \%$ (Farhadian, Jinap, Abas, \& Sakar, 2010; Ishizaki, Saito, Hanioka, Narimatsu, \& Kataoka, 2010; Iwasaki et al., 2010; Janoszka, 2011). Recovery rate could be affected by sorbing materials, flow rate through cartridges, organic modifier quality and/or content, interfering effects of eluting solvents (Busetti, Heitz, Cuomo, Badoer, 
291

292

293

294

295

296

297

298

299

300

301

302

303

304

305

306

307

308

309

310

311

312

\& Traverso, 2006). Stevens, Hamstra, Hegeman \& Scharrer (2006) reported that overlapping peaks on chromatogram caused by insufficient separation procedures could result in recovery rate over $110 \%$, and AOAC (2016) recommends that $40-120 \%$ recovery rate is acceptable for compounds at $1 \mathrm{ng} / \mathrm{g}$ concentration.

\subsection{Inhibitory rate of HCAs and PAHs}

Inhibitory rate was determined according to the equation:

Inhibitory rate $(\%)=\left(A_{c}-A_{t}\right) / A_{c} \times 100$

where $A_{c}$ was the total amount of HCAs/PAHs in control samples (ng/g), and $A_{t}$ was the total amount of HCAs/PAHs in fat partially replaced patties (S/ O/ G patties) (ng/g).

\subsection{Physical parameters}

\subsubsection{Colour}

Colour feature including $L^{*}, a^{*}$ and $b^{*}$ was measured using Hunter Lab Colour instructment (Hunter Associates Laboratory, Virginia, USA, 2003). Each sample was measured at 3 different locations, while the average was recorded as the colour feature of the sample.

\subsubsection{Texture}

Texture profile analysis (TPA) was performed at room temperature with a Stable system Texture Analyzer (Middleboro, USA).Cyclinder samples ( $D=18 \mathrm{~mm}, \mathrm{H}=22 \mathrm{~mm}$ ) were prepared using a stainless cork borer. Before the analysis, samples were tempered at room temperature $\left(20^{\circ} \mathrm{C}\right)$ for $30 \mathrm{~min}$. The settings for texture analysis were: load cell $5 \mathrm{~kg}$, head speed $1.6 \mathrm{~mm} / \mathrm{s}$, and compression depth $10.0 \mathrm{~mm}$. The 
calculation of TPA values was based on the compression curve with force (y-axis) and time (x-axis). Values for hardness $(\mathrm{N})$ was defined as the absolute peak force in the $1^{\text {st }}$ compression cycle, cohesiveness as the area of work in the $2^{\text {nd }}$ compression divided by the area of work in the $1^{\text {st }}$ compression, chewiness as the product of hardness ${ }^{*}$ cohesiveness ${ }^{*}$ springiness, and springiness as the force that sample return to its initial pattern after compression (Sánchez del Pulgar, Gázquez \& RuizCarrascal, 2012). Each sample was measured at least 5 times, and the average was recorded as the value of the sample.

\subsection{Statistical analysis}

Each treatment had three replicates. Statistical significance test was carried out by using SPSS Statistics 21 (IBM, 2014). The significant difference in chemical composition, physical property, levels of HCAs and PAHs for the 8 treatments were carried out by one-way analysis of variance (ANOVA) at the significant level 0.05 , and Duncan test was selected for multiple comparison if equal variances assumed, otherwise Tamhane's T2 test was used. To analyse the effect of factors and the interaction between factors (cooking temperature and replacing oil type), two-way ANOVA was employed at the significant level 0.05 . Multivariate linear regression model was employed to explore the effect of multi independent factors, including lipid oxidation, protein oxidation and antioxidant capacity of oils on the formation of HCAs and PAHs at the significant level 0.05 . Pearson correlation was employed for the measurements as a prerequisite for the regression.

\section{Results and discussion}

\subsection{Effect of replacing oil and cooking temperature on proximate composition} and physical parameters of reduced fat pork patties 


\subsubsection{Proximate composition}

338

Table 2 shows that the effect of replacing oil and cooking temperature on proximate composition and $\mathrm{pH}$ values in patties. Type of replacing oil did not pose any effect on all proximate composition and $\mathrm{pH}$, but cooking temperature had significant influence on moisture and cooking loss $(p<0.01)$. Interaction between type of oil and cooking temperature was only observed in cooking loss $(p<0.01)$.

Moisture content varies from $63.36 \pm 0.37 \%$ to $67.53 \pm 0.26 \%$ in fat partially replaced patties, which are consistent with the results reported by RodríguezCarpena et al. (2012). They found that pork patties with $50 \%$ fat replaced with sunflower oil, olive oil and avocado oil had moisture level at $61.48-63.39 \%$ when patties were cooking at $170{ }^{\circ} \mathrm{C}$ for $18 \mathrm{~min}$ in a forced-air oven. There was no significant difference in moisture content for all the patties (with or without fat replacement) $(p=0.206)$, which indicated that replacing back fat with vegetable oils did not affect moisture level in the final products. However, cooking temperature significantly affected the moisture content in the final products $(p<0.05)$. Higher cooking temperature at $220^{\circ} \mathrm{C}$ led to low moisture level in cooked patties, compared with low cooking temperature at $180^{\circ} \mathrm{C}(\mathrm{p}<0.01)$, which were $63.58 \%$ vs $69.15 \%$ for control, $63.36 \%$ vs $65.91 \%$ for olive oil treatment, $63.49 \%$ vs $66.34 \%$ for sunflower oil treatment and $65.90 \%$ vs $67.53 \%$ for grape seed oil treatment. Low moisture level in the final products are directly associated with high cooking loss, as cooking loss is mainly composed of water and water soluble nutrients such as proteins (Sánchez del Pulgar et al., 2012). Pork patties with or without fat replacement had cooking loss ranging from $20.30 \%-24.75 \%$,which was consistent with the results reported by Rodr'ıguez-Carpena, Morcuende and Est'evez (2011). They found that cooked pork 
361

362

363

364

365

366

367

368

369

370

371

372

373

374

375

376

377

378

379

380

381

382

383

384

patties at $170{ }^{\circ} \mathrm{C}$ for $18 \mathrm{~min}$ had cooking loss at $20.69 \%-22.20 \%$. Fat and protein content ranged from $9.49 \%-10.01 \%$ and $15.03 \%-15.34 \%$ respectively, as expected, fat and protein content in fat modified patties were comparable with these in $\mathrm{C}$ patties. $\mathrm{pH}$ ranged from 5.85 to 5.99 . Cooking temperature and type of oil did not affect $\mathrm{pH}$ of patties, there was no interaction between temperature and type of oil as well $(p>0.05)$.

\subsubsection{Physical parameters}

\subsubsection{Texture}

Texture property of cooked pork patties was examined including hardness, cohesiveness, springiness and chewiness through a typical texture profile analysis. Results were listed in Table 3. Cooking temperature affected hardness, cohesiveness and chewiness ( $\leq \leq 0.05)$, but had no effect on springiness $(p>0.05)$. Fat replacement with vegetable oils did not affect any of the texture attributes $(p>0.05)$. There was no interaction observed between oil replacement and temperature for hardness, chewiness and springiness except cohesiveness $(p>0.05)$.

High cooking temperature led to high hardness. Control patties cooked at $220^{\circ} \mathrm{C}$ had significantly higher hardness $(26.65 \pm 3.15 \mathrm{~N})$ than that cooked at $180^{\circ} \mathrm{C}(20.14 \pm 2.81 \mathrm{~N})$ $(p<0.05)$. Roldán et al. (2013) observed that the elevating cooking temperature resulted in higher hardness, while the increased hardness in pork patties might be associated with high cooking loss. There was no difference observed in hardness for fat modified patties regardless of temperature $(p>0.05)$, which agreed with the results reported by Rodr'ıguez-Carpena et al. (2011). They stated that patties that partially (50\%) replaced with sunflower oil, olive oil and avocado oil had same hardness with control patties. However, Hur, Jin and Kim (2008) reported that olive oil replacement 
in pork patties resulted in low hardness compared with control patties. The cooking temperature could help to explain the disagreement. In their study, patties were cooked at $100^{\circ} \mathrm{C}$ in water bath, while samples were cooked in convection oven at $180^{\circ} \mathrm{C}$ or $220^{\circ} \mathrm{C}$. The hardening effect of high cooking temperature could be neutralized by the softening effect of to the replacing vegetable oil. As a result, there was no difference observed in hardness for fat modified patties and control sample $(p>0.05)$

Temperature affected cohesiveness greatly $(p=0.001)$, because the texture parameters are mainly determined by denaturation of the structural protein system, i.e. actomyosin complex and collagen (Palka \& Daun, 1999). Type of oil did not have any effect on the cohesiveness of pork patties ( $p>0.05)$. Rodríguez-Carpena et al. (2012) also reported that there was no difference in cohesiveness between control and patties with $50 \%$ fat substitution using avocado, sunflower or olive oil. The interaction between temperature and type of oil on cohesiveness was observed $(p<0.05)$. For control, olive and sunflower oil treatment, patties cooked at $220^{\circ} \mathrm{C}$ had higher cohesiveness than these cooked at $180^{\circ} \mathrm{C}(p<0.05)$, but there was no difference in cohesiveness for grape seed oil samples cooked at different temperatures $(p>0.05)$. This interaction between cooking temprature and type of oil could be explained by the emulsion stability of oil/fat emulsion. Youssef and Barbut (2009) and Rodr'iguez-Carpena et al. (2011) reported that vegetable oil with high polyunsaturated fatty acids (PUFA) had small fat globules in meat emulsion, which could offer a stronger fat-protein interaction. Grape seed oil contained high level of PUFA compared with back fat and olive oil, which led to a stable emulsion in G patties. In addition, polyphenol compounds in grape seed oil emulsion could help maintain the protein functionality through inhibition of protein oxidation during 
410

411

412

processing (Ganhão, Morcuende \& Estévez, 2010). Thus, grape seed oil/meat emulsion was less sensitive to temperature changes in relation to cohesiveness of the final products.

For chewiness, temperature significantly affected it $(p<0.05)$. High cooking temperature resulted in high chewiness. Chewiness remained similar for all patties cooked at $180^{\circ} \mathrm{C}$ (from 3.94 to $4.11 \mathrm{~N} . \mathrm{s}$ ), but increased to $5.92 \pm 0.77 \mathrm{~N} . \mathrm{s}$ in $\mathrm{C}$ patties, and $5.35 \pm 0.41$ N.s in $S$ patties that cooked at $220{ }^{\circ} \mathrm{C}$. Greater hardness, cohesiveness and chewiness at higher elevating cooking temprature could be due to the more severe denaturation of myosin $\left(40-60{ }^{\circ} \mathrm{C}\right)$ and actin $\left(66-73^{\circ} \mathrm{C}\right)($ Sánchez del Pulgar et al., 2012). In addtion, chewiness is also associated with the water retention in meat products (Roldán et al., 2014). Patties cooked at $180^{\circ} \mathrm{C}$ had significantly higher mositure content than thoes cooked at $220^{\circ} \mathrm{C}$ (as shown in Table 2). Therefore, high chewiness would be expected in samples cooked at $220^{\circ} \mathrm{C}$ due to high moisture loss.

\subsubsection{Colour}

Effects of vegetable oil and cooking temperature on colour characteristics of cooked pork patties including lightness $\left(L^{*}\right)$, redness $\left(a^{*}\right)$ and yellowness $\left(b^{*}\right)$ were summarized in Table 3 . Temperature significantly affected all three parameters $(p \leq$ 0.05 ), especially $a^{*}$ with $p=0.005$. Different vegetable oils did not have any impact on the colour parameters, while the interaction between oil and temperature was observed in yellowness $\left(b^{*}\right)$. Patties cooked at $220^{\circ} \mathrm{C}$ had lower $L^{*}$ than those cooked at $180^{\circ} \mathrm{C}(\mathrm{p}<0.01)$, which agreed with the results of Sánchez del Pulgar et al. (2012). The decrease in surface lightness could be attributed to the brown pigments formed from caramelization of sugars and Maillard reaction when samples were 
cooked at temperature over $90^{\circ} \mathrm{C}$ (Girard, 1992). In addition, the lightness was also associated with the moisture content in meat products. Qiao et al. (2001) reported that there was positive correlation between lightness and moisture content in broiler breast fillet. Presence of heme pigments, containing 90-95\% myoglobin in muscles gives meat red colour $\left(a^{*}\right)$. At $180^{\circ} \mathrm{C}$, a higher $\mathrm{a}^{*}$ value was found in all pork patties with oil replacement than control patties $(p<0.05)$. The antioxidants in these vegetable oils, such as vitamin E could prohibit the oxidation of oxymyoglobin and lead to a high redness in the final products (Hui, 2001; Sánchez del Pulgar et al., 2012). Cooking temperature could significantly affect $a^{*}$ as well. All patties that cooked at $220^{\circ} \mathrm{C}$ had significantly lower $\mathrm{a}^{*}$ than those cooked at $180{ }^{\circ} \mathrm{C}$. The reduction of $a^{*}$ caused by increased temperature could be associated with the denaturation of myoglobin (Nollet, 2012). Liao, Xu and Zhou (2009) found that $a^{*}$ of stir fried pork floss decreased significantly by $30 \%$ when cooking temperature increased from $125^{\circ} \mathrm{C}$ to $150^{\circ} \mathrm{C}$.

Yellowness $b^{*}$ ranged from $15.41-18.73$ in all cooked patties. Both type of oil and cooking temperature had no effect on $b^{*}$ values, but the interaction between type of oil and cooking temperature was observed. Jamali et al. (2016) also found that b* value in beef patties was not affected by cooking temperature $\left(160^{\circ} \mathrm{C}\right.$ and $\left.220^{\circ} \mathrm{C}\right)$. The results of $b^{*}$ in control samples (16.98-18.73) were comparable with Vittadini et al. (2005).

\subsection{Effects of vegetable oils and cooking temperature on the formation of} HCAs

Concentration of HCAs (IQ, MelQ, MelQx, 4, 8-DiMelQx and PhIP) in control patties and fat modified patties cooked at $180^{\circ} \mathrm{C}$ and $220^{\circ} \mathrm{C}$ were listed in Table 4. Type of 
oil affected all individual HCAs compound except IQ, cooking temperature significantly affected the total amount of HCAs and all individual HCAs compounds except MelQx. Interaction between oil and cooking temperature was observed in total HCAs, IQ, MelQ, 4, 8-DiMelQx and PhIP, but not MelQx. At both temperatures, all fat modified patties had significantly lower amount of MelQ, 4, 8-DiMelQx and total HCAs than control patties $(p<0.05)$. MelQx, 4, 8- DiMelQx and PhIP were not detectable in $\mathrm{G}$ patties. Tocopherols (average $50 \mathrm{mg} / 100 \mathrm{~g}$ in sunflower oil, 100$300 \mathrm{mg} / \mathrm{g}$ in refined olive oil and $10-15 \mathrm{mg} / \mathrm{g}$ in grape seed oil) and polyphenols (common profile in grape seed oil: catechin, epicatechin and epicatechin gallate) in these oils could play roles in reducing the final HCAs in patties (Bail et al., 2008; McCance \& Widdowson, 2002; Rombaut et al., 2014). Tocopherols have been found to block dialkyl-pyrazine radicals for further reaction with creatine to form HCAs, or react with precursors of 4, 8-DiMelQx to inhibit the formation of HCAs (Pearson et al., 1992; Vitaglione \& Fogliano, 2004). Phenolic compounds could also prevent the formation of imidazoquinoxaline-type HCAs through trapping pyrazine cation radicals and some other carbon-centred radicals generated either from pyrazine cation radicals or different pathway during Maillard reaction (Kato et al., 1996). In addition, phenolic compounds have the ability to directly trap phenylacetaldehyde, which is a major intermediate during the formation of PhIP (Cheng et al., 2007).

Total HCAs ranged from not detected $(\mathrm{Nd})$ to $140.57 \pm 22.03 \mathrm{ng} / \mathrm{g}$. Control patties cooked at both cooking temperatures contained significantly higher amount of total HCAs $(67.56 \pm 17.29 \mathrm{ng} / \mathrm{g}$ and $140.57 \pm 22.03 \mathrm{ng} / \mathrm{g})$, followed by $S$ patties $(5.98 \pm$ $1.10 \mathrm{ng} / \mathrm{g}$ and $23.88 \pm 2.44 \mathrm{ng} / \mathrm{g})$ and $O$ patties $(4.11 \pm 0.87 \mathrm{ng} / \mathrm{g}$ and $20.03 \pm 2.25$ $\mathrm{ng} / \mathrm{g}$ ), while G patties achieved the lowest total HCAs in both temperatures (Nd and $1.90 \pm 0.04 \mathrm{ng} / \mathrm{g}$ ). Control samples cooked at $220^{\circ} \mathrm{C}$ contained all types of HCAs, 
whereas none of $\mathrm{HCA}$ compounds were detected in $\mathrm{G}$ patties cooked at $180^{\circ} \mathrm{C}$. The dominating compounds of HCAs were MelQ $(59.70 \pm 0.98 \mathrm{ng} / \mathrm{g})$ and 4, 8-DiMelQx $(43.37 \pm 15.67 \mathrm{ng} / \mathrm{g})$ in C patties, while PhIP in $S(14.78 \pm 1.49 \mathrm{ng} / \mathrm{g})$ and $\mathrm{O}$ patties $(22.70 \pm 1.95 \mathrm{ng} / \mathrm{g})$. The total HCAs in C patties were higher than some published results. Vangnai et al. (2014) reported MelQx (7.59 $\pm 0.43 \mathrm{ng} / \mathrm{g})$, PhIP $(13.12 \pm 0.72$ $\mathrm{ng} / \mathrm{g})$ and total HCAs $(22.35 \pm 1.17 \mathrm{ng} / \mathrm{g})$ in fried pork loins cooked at $204^{\circ} \mathrm{C}$ for 16 minutes. The total level of HCAs in pan-fried well-done pork was $49.7 \mathrm{ng} / \mathrm{g}$ with cooking ended at $80{ }^{\circ} \mathrm{C}$ core temperature (Iwasaki et al., 2010). The sampling procedure for measuring HCAs could help explain the difference. HCAs were extracted from the $2 \mathrm{~mm}$ outer layer surface of samples in this study, while lots of researchers extracted HCAs from entirely ground samples. The precursors of HCAs, such as creatine, glucose and free amino acids would migrate to the surface of meat and enhance Maillard reactions during cooking (Gibis \& Weiss, 2015). As a result, surface could accumulate much higher level of HCAs compared with internal part of the sample. Therefore, a higher concentration of HCAs would be expected than that exacted from entirely ground samples.

IQ was detected up to $3.88 \mathrm{ng} / \mathrm{g}$ in cooked patties, which was in the range of $0.7-5.3$ $\mathrm{ng} / \mathrm{g}$ in fried ground beef patties (Balogh et al., 2000). At $180^{\circ} \mathrm{C}$, IQ was not detected apart from $\mathrm{O}$ patties, but cooking at $220^{\circ} \mathrm{C}$ generated high level of IQ in all patties $(p<0.05)$. Different vegetable oils did not affect the formation of $I Q(p>0.05)$, but interaction between vegetable oil and temperature was observed in formation of IQ. $I Q$ is generally formed through reactions between creatinine, pyridine radicals and formaldehydes (Vitaglione \& Fogliano, 2004). Vegetable oils could decompose into hydroperoxides, and then aldehydes and ketones at high cooking temperature, which further react with amino acids in Maillard reactions (Johansson, Skog, \& 
Jagerstad, 1993; Zamora \& Hidalgo, 2007). Olive oils with high level of oleic acid could decompose into aldehydes (-CHO) much faster (3-15 times) than sunflower oil and grape seed oil containing high amount of linoleic and linolenic acid at $190^{\circ} \mathrm{C}$ (Guillén \& Uriarte, 2012b). This might explain why IQ was only detected in olive oil patties at $180^{\circ} \mathrm{C}$. But the pathway of formation of HCAs in the real meat system was more complicated than chemical model system, and antioxidants in oils should also be considered (Johansson, Skog, \& Jagerstad, 1993). Therefore, further investigation is needed to understand promoting mechanism and role of antioxidants in oils. The highest MelQ was found in control patties cooked at $220^{\circ} \mathrm{C}(59.70 \pm 0.98$ $\mathrm{ng} / \mathrm{g})$, followed by in control patties cooked at $180^{\circ} \mathrm{C}(18.26 \pm 14.46 \mathrm{ng} / \mathrm{g})$. Janoszka (2010) reported that $6.28 \mathrm{ng} / \mathrm{g} \mathrm{MelQ}$ was detected in pan-fried pork patties cooked at $170^{\circ} \mathrm{C}$ for 12 minutes, which was similar with this study. Formation of MelQ was completely inhibited by olive oil and sunflower oil at both cooking temperatures. Grape seed oil could only inhibit formation of MelQ at low cooking temperature, while $1.31 \mathrm{ng} / \mathrm{g}$ was detected in $\mathrm{G}$ patties cooked at $220^{\circ} \mathrm{C}$. The inhibitory effect on MelQ could be attributed to the antioxidants such as vitamin E and polyphenols in vegetable oils. Rounds et al. (2012) and Liao et al. (2009) also reported that vitamin E and polyphenols could reduce the formation of MelQ. Balogh et al. (2000) found that vitamin $\mathrm{E}$ had stronger inhibitory effect on MelQ with reduction rate $64.3 \%$ than phenolic compound in Oleoresin rosemary extract with reduction rate $47.9 \%$ in fried beef patties. Since olive oil and sunflower oil contain higher level of vitamin $E$ than grape seed oil, therefore, stronger inhibition of MelQ would be expected in O patties and $S$ patties. Cooking temperature did not affect MelQx level in patties $(p>0.05)$, but formation of MelQx was significantly affected by different vegetable oils. S patties and $O$ patties had similar MelQx with control sample. For $G$ patties cooked at both 
temperatures, there was no MelQx detected. However, sunflower oil and olive oil did not affect MelQx in patties, although both oils were rich of vitamin E. No MelQx was detected at all which was in agreement with Rounds et al. (2012), who also reported grape seed extract could completely inhibit the formation of MelQx in cooked beef patties. Temperature significantly increased formation of 4, 8-DiMeIQx as evidenced in $\mathrm{C}$ patties cooked at $180^{\circ} \mathrm{C}$ and $220^{\circ} \mathrm{C}(25.66 \pm 1.51 \mathrm{ng} / \mathrm{g}$ and $43.37 \pm 15.67 \mathrm{ng} / \mathrm{g})$ $(p<0.05)$. All vegetable oils effectively reduced 4, 8-DiMelQx in patties. Grape seed oil was the most effective one among the three vegetable oil as 4, 8-DiMelQx was not detected in $\mathrm{G}$ patties cooked at both temperatures.

PhIP ranged from Nd to $24.07 \pm 1.99 \mathrm{ng} / \mathrm{g}$. A similar level of PhIP $(18.4 \pm 11.5 \mathrm{ng} / \mathrm{g})$ in the fried pork patties was reported by Zhang et al. (2013), when patties were cooked at $180^{\circ} \mathrm{C}$ for $5 \mathrm{~min}$. At $180{ }^{\circ} \mathrm{C}, \mathrm{PhIP}(11.43 \pm 6.33 \mathrm{ng} / \mathrm{g})$ was totally inhibited by all 3 vegetable oils, but only grape seed oil could completely inhibit the formation of PhIP at both cooking temperatures. The stronger inhibitory effect on PhIP in G patties could be attributed to the phenolic compounds in grape seed oil. Gibis and Weiss (2012), Jamali et al. (2016) and Oguri et al. (1998) found that catechin, epicatechin and epicatechin-3-O-gallate in grape seed extract may be responsible for $50 \%-90 \%$ reduction of PhIP in both oven cooked beef patties and chemical model system. Zamora and Hidalg (2015) suggested phenolic compounds could effectively scavenge the carbonyl compounds in the Strecker degradation of phenylalanine to produce phenylacetaldehyde (major intermediate in the development of PhIP). Temperature significantly affected PhIP level in pork patties $(p<0.05)$. PhIP increased significantly in $C$ patties from $11.43 \pm 6.33 \mathrm{ng} / \mathrm{g}$ to $24.07 \pm 1.99 \mathrm{ng} / \mathrm{g}, \mathrm{O}$ patties from $\mathrm{Nd}$ to $14.78 \pm 1.49 \mathrm{ng} / \mathrm{g}$ and $\mathrm{S}$ patties from $\mathrm{Nd}$ to $22.70 \pm 1.95 \mathrm{ng} / \mathrm{g}$ when cooking temperature increased from $180^{\circ} \mathrm{C}$ to $220^{\circ} \mathrm{C}(\mathrm{p}<0.05)$. The results agreed 
with Gibis and Weiss (2012) and Wong et al. (2012) that PhIP level was directly related to the cooking temperature. At $175-200{ }^{\circ} \mathrm{C}$, only very low level of PhIP (0$6.91 \mathrm{ng} / \mathrm{g}$ ) could be formed even at varied cooking time, but it could increase dramatically to $31.80 \mathrm{ng} / \mathrm{g}$ with prolonged cooking time if temperature went above $200^{\circ} \mathrm{C}$.

Type of vegetable oil significantly affected the level of total HCAs in cooked patties $(p<0.05)$, but temperature did not have any effect $(p>0.05)$. Interaction between types of vegetable oil and cooking temperature was observed as well $(p<0.05)$. In the current study, reduction of total HCAs by $85.75 \%-93.90 \%$ was found in O patties, $83.01 \%-91.15 \%$ in $S$ patties, while $\mathrm{G}$ patties achieved the highest reduction rate at $98.64 \%-100 \%$ (Table 4). Antioxidants in the vegetable oils could be responsible for the reduction of total HCAs as a strong negative correlation $(r=-0.618, p<0.01)$ was disclosed between total HCAs level and antioxidant capacity (TEAC) of oils (Table 6). Grape seed oil had the highest TEAC value with $0.71 \pm 0.01 \mu \mathrm{mol}$ Trolox/100g, followed by olive oil $(0.52 \pm 0.05 \mu \mathrm{mol}$ Trolox $/ 100 \mathrm{~g})$ and sunflower oil $(0.18 \pm 0.04 \mu \mathrm{mol}$ Trolox/100g), while pork back fat had the lowest TEAC value $(0.09 \pm 0.02 \mu \mathrm{mol}$ Trolox/100g) (Figure 1). Therefore, reduction of HCAs in vegetable oils, especially grape seeds oil was expected compared with control sample. Results were comparable with findings of Matthäus (2008) and Castelo-Branco and Torres (2012). Balogh et al. (2000) found that $1 \%$ vitamin E spray on the surface of beef patties could reduce the concentrations of IQ, MeIQ, MelQx, DiMelQx and PhIP significantly by $45 \%$ to $75 \%$, because vitamin $\mathrm{E}$ could remove free radicals in Maillard reactions. Similar result was also reported by Lan, Kao and Che (2004). They found that $70 \%$ of total HCAs (IQ, MelQ, MelQx, 4, 8-DiMelQx and PhIP) were prohibited when 0.2\% a-tocopherol was added into ground pork $1 \mathrm{~h}$ before cooking. Phenolic compounds, 
such as catechin, epicatechin-3-O-gallate, oligomer procyanidins and tocopherols in grape seed oil contributed to its antioxidant capacity (Agostini et al., 2012; Crews et al., 2006; Matthäus, 2008). Vitaglione and Fogliano (2004) suggested that mixture of antioxidant compounds could perform better than single antioxidant as they could inhibit various pathways in different steps of reactions. Therefore, phenolic compounds might work synergistically with tocopherols to enhance each other to inhibit the formation of HCAs. However, the synergistic effect between different antioxidants needs to be further examined.

Cooking temperature significantly affected total HCAs in pork patties $(p<0.01)($ Table 4). Patties cooked at $220^{\circ} \mathrm{C}$ had significantly higher level of toal HCAs than these at $180^{\circ} \mathrm{C}(p<0.01)$. Effect of temperature on the formation of HCAs was well examined in previous research (Knize et al., 1994; Liao et al., 2009; Oz \& Kaya, 2011). Thermal processing has vital influence on the formation of polar HCAs (IQ, MeIQ, MelQx, DiMelQx and PhIP), which are formed in meat products when samples are cooked at $160-250{ }^{\circ} \mathrm{C}$, typical domestically cooking temperature. High cooking temperature generated more diverse types of HCAs, but also stimulate the accumulation of the amount of HCAs on the surface of meat products (Olsson \& Pickova, 2005; Skog, Johansson \& Jaègerstad, 1998).

\subsection{Effects of vegetable oils and cooking temperature on the formation of}

\section{PAHs}

Concentration of PAHs ( $\mathrm{BaA}$ and $\mathrm{BaP})$ in cooked pork patties with different cooking temperature was listed in Table 5. The range of total PAHs was from $1.59 \pm 0.26 \mathrm{ng} / \mathrm{g}$ to $3.84 \pm 0.21 \mathrm{ng} / \mathrm{g}$. The dominating compound of PAHs was $\mathrm{BaP}$ in all samples. BaA ranged from $0.14-0.31 \mathrm{ng} / \mathrm{g}$ in cooked patties, while $\mathrm{BaP}$ ranged from 1.44 to 
607

608

609

610

611

612

613

614

615

616

617

618

619

620

621

622

623

624

625

626

627

628

629

630

631

3.53ng/g. Temperature did not affect the formation of both $\mathrm{BaA}$ and $\mathrm{BaP}$, but type of vegetable oil had significant effect on the formation $(p<0.05)$. Interaction between type of oil and cooking temperature was also observed in both compounds (Table 5).

BaP level in this study (1.44-3.53 ng/g) are consistent with results reported by Nisha et al. (2015) and Janoszka (2011), i.e. $1.52 \mathrm{ng} / \mathrm{g}$ of BaP in the oven broiled pork and $1.61 \mathrm{ng} / \mathrm{g} \mathrm{BaP}$ in oven grilled pork chop $\left(17 \mathrm{~min}\right.$ at $\left.170^{\circ} \mathrm{C}\right)$. Olive oil and grape seed oil showed inhibitory effect on BaP when patties cooked at $220^{\circ} \mathrm{C}$, but no effect or even promoting effect was observed at $180^{\circ} \mathrm{C}$. On the contrast, sunflower oil offered inhibition on $\mathrm{BaP}$ at $180^{\circ} \mathrm{C}$, but promotion at $220^{\circ} \mathrm{C}$. As $\mathrm{BaP}$ is one of the highest toxic potency compounds during meat cooking, EU Commission has regulated that the updated limit of BaP occurring in processed meat and seafood products is $2 \mathrm{ng} / \mathrm{g}$ (Purcaro et al., 2013; Wretling et al., 2010). Among all the patties, only O patties cooked at $220^{\circ} \mathrm{C}$ and $\mathrm{S}$ patties cooked at $180^{\circ} \mathrm{C}$ met the safety regulation of BaP. Therefore, it is necessary to develop any procedures or alternative methods that reduce the amount of $\mathrm{BaP}$ to safety limit.

The effect of oil and interaction between type of oil and cooking temperature on the formation of PAHs were significant $(p<0.05)$. Cooking temperature did not affect the formation of PAHs $(p>0.05)$. S patties cooked at $220^{\circ} \mathrm{C}$ had the highest total PAHs $(3.84 \pm 0.21 \mathrm{ng} / \mathrm{g})$, followed by $\mathrm{G}$ patties $(3.46 \pm 0.16 \mathrm{ng} / \mathrm{g})$ cooked at $180{ }^{\circ} \mathrm{C}$ and $\mathrm{C}$ patties $(3.28 \pm 0.07 \mathrm{ng} / \mathrm{g})$ cooked at $220^{\circ} \mathrm{C}$. O patties cooked at $220^{\circ} \mathrm{C}$ obtained the lowest PAHs. PAHs were mainly associated with the pyrolysis of fat undertaken at high temperature (Viegas et al., 2012). Therefore, smoking point of vegetable oils may help explain the difference in PAHs. Sunflower oil and grape seed oil contain high content of PUFAs, especially linolenic acid and linolenic acid have lower smoke points (grape seed oil $216^{\circ} \mathrm{C}$, sunflower oil $227^{\circ} \mathrm{C}$ ) which makes them easy to 
632

633

634

635

636

637

638

639

640

641

642

643

644

645

646

647

648

649

650

651

652

653

654

655

decompose, compared with olive oil (smoke point $242^{\circ} \mathrm{C}$ ). The decomposition of oil could generate more reactive free radicals to accelerate the production of PAHs (Chen \& Lin, 1997; Elmore et al., 2002). They also concluded that hydroperoxides from lipid oxidation, could subsequently generate cyclic compounds through intramolecular reaction, and PUFA could undergo further polymerization. In addition, vegetable oils themselves contained $\mathrm{BaP}$, which might increase the total amount of PAHs in cooked meat. Fromberg, Højgard and Duedahl-olesen (2007) reported that olive oil, sunflower oil, and grape seed oil approximately contained $0.12 \mathrm{ng} / \mathrm{g}, 0.4$ $\mathrm{ng} / \mathrm{g}$ and $1.0 \mathrm{ng} / \mathrm{g} \mathrm{BaP}$ respectively. As a result, high level of PAHs was expected in sunflower oil and grape seed oil samples. Although vegetable oils contain antioxidants, the inhibitory effect on PAHs formation was not observed consistently. In $S$ patties, the inhibitory efficiency at both temperature were $7.75 \%$ and $51.52 \%$, but olive oil and grape seed oil increased the formation of PAHs by $17.07 \%$ and $34.11 \%$, respectively. It shows that antioxidants in vegetable oils were not involved in the formation of PAHs to a great extent, which is further confirmed by the correlation analysis. As indicated in Table 6, there is no correlation relationship observed between antioxidant capacity of oil (TEAC) and total PAHs. The impact of tocopherols and phenolic compounds on the formation of PAHs in processed meat were not well documented. In vitro study, Zhu et al. (2014) found that vitamin E intake could significantly prohibit free radicle induced by $\mathrm{BaP}$ and protect cellular damage in human lung, but the effect antioxidants on formation of PAHs in food products has been scarce.

\subsection{Correlation between lipid oxidation, protein oxidation and the formation of} HCAs and PAHs 
656

657

658

659

660

661

662

663

664

665

666

667

668

669

670

671

672

673

674

In Figure 2, S patties, O patties and $\mathrm{G}$ patties had significantly lower TBARS values than control samples $(p<0.05)$, while $G$ patties had the lowest TBARS value compared with $\mathrm{O}$ and $\mathrm{S}$ patties $(\mathrm{p}=0.001)$. This inhibitory effect against lipid oxidation could be attributed to the antioxidants (tocopherols and phenolic compounds) within the oils, since a significantly negative relationship was found between TBARS values and antioxidant capacity of oils $(r=-0.764, p<0.01)$. Wong et al. $(2015)$ reported that $0.1-0.4 \mathrm{mmol}$ vitamin $\mathrm{E}$ could inhibit $45 \%$ of lipid oxidation in beef patties, by obstructing the formation of some key aldehydes and ketones during lipid oxidation. Similar results were achieved by Ahn, Grün and Fernando (2002) as well. Frankel (1998) proposed that a-tocopherol could prevent the chain propagating and remove free radicals through reacting with either singlet oxygen or peroxyl radicals. Consequently lipid oxidation was reduced. Meanwhile, polyphenols, such as epicatechin (EC) oligomer procyanidins were also sufficient to inhibit lipid oxidation by reducing free radicles and preventing chain propagation in cooked pork and beef (Rojas \& brewer, 2007). They could also chelate metals (iron and cooper in meat) or react with ROS, and then turn into non-radical species. As a result, reactions were terminated (Roman et al., 2013). Moreover, Ahn et al. (2002) and Tang et al. (2001) reported that polyphenols such as catechin, epicatechin were more efficient in inhibiting lipid oxidation than $\alpha$-tocopherol at the same concentration in cooked meat. This could explain why $G$ patties had the lowest TBARS values than $S$ and $O$ patties. Although Gunstone (2002) stated that a higher degree of unsaturation of fatty acids could be easier to trigger the lipid oxidation and interacted with Maillard reaction, the presence of antioxidants should be also considered in the formation of HCAs.

Protein carbonyls are produced from protein oxidative degradation in meat products, which were used to analyse degree of protein oxidation (Figure 3). Significant effect 
681

682

683

684

685

686

687

688

689

690

691

692

693

694

695

696

697

698

699

700

701

702

703

704

705

of vegetable oils on the protein oxidation was observed $(p=0.001)$. C patties had a significantly higher level of protein carbonyls $(12.11 \mathrm{mmol} / \mathrm{kg})$ than other 3 fat modified patties $(p<0.05)$. The protein oxidation could be inhibited by the presence of antioxidants in oil, as negative correlation between antioxidant capacity of oils (TEAC) and protein carbonyl level was found with $r=-0.606, p<0.01$, as indicated in Table 6 . Botsoglou et al. (2014) found that protein carbonyl value could be reduced from 3.25 $\mathrm{mmol} / \mathrm{kg}$ to $2.25 \mathrm{mmol} / \mathrm{kg}$ in cooked pork patties when $50 \mathrm{mg} / \mathrm{kg}$ a-tocopherol was added. Vuorela et al. (2005) reported that phenolic compounds, including vinylsyringol and sinapic acid in rapeseed oil had good antioxidant capacity against protein oxidation in cooked pork patties. Ganhão et al. (2010) also found that arbutus-berries extract containing catechins significantly reduced protein oxidation by chelating heme iron in cooked patties. However, there was no difference in the protein carbonyl level among $\mathrm{O}, \mathrm{S}$ and $\mathrm{G}$ patties $(\mathrm{p}>0.05)$.

In the development of HCAs under high temperature cooking, both lipid oxidation and protein oxidation are involved with Maillard reactions in the meat system (Johansson, Skog \& Jagerstad, 1993; Zamora \& Hidalgo, 2007). Lot of researchers believed that formation of HCAs could be primarily related to interactions between free radicals generated from lipid oxidation and free radicals produced in Maillard reactions (Hwang \& Ngadi, 2002; Skog et al., 1998). Therefore, it is useful to explore the relationship between lipid/protein oxidation and the formation of HCAs. In this study, correlation analysis was conducted between TBARS/protein carbonyl values and concentration of total HCAs in fat modified cooked patties (Table 6). Significant positive correlation was disclosed between total HCAs and TBARS $(r=0.826, p<0.01)$ and between HCAs and protein carbonyl $(r=0.778, p<0.01)$, which further confirmed that both lipid oxidation and protein oxidation participated the formation of HCAs 
706

707

708

709

710

711

712

713

714

715

716

717

718

719

720

721

722

723

724

725

726

727

728

729

during cooking process. In order to further examine the relationship between lipid oxidation/protein oxidation/antioxidant capacity of lipids and total HCAs in cooked patties, multivariate linear regression model was displayed below,

Total HCAs $=-42.37+108.26$ * TBARS +5.647 * Protein Carbonyl.

It can be seen from the equation that TBARS (lipid oxidation) played a predominant role on the formation of HCAs, compared with protein carbonyl (protein oxidation).

The factor 'TEAC (antioxidant capacity of lipids)' has been removed from the model, because the strong correlation between TEAC and TBARS/protein carbonyl indicates that variance accounted for TEAC could be well accounted by TBARS/protein carbonyl. In cross-validation, adding/removing 'TEAC' caused little change in adjusted $\mathrm{R}$ square of the predicted models, which indicated variance caused by TEAC could be well explained by other independent factors in the model (Field, 2009).

Free radicals, such as aldehydes and ketones generated from lipids oxidation could interact with Maillard reactions by reacting with the polar head of an amino group to produce more HCAs (Jägerstad et al., 1998; Zamora \& Hidalgo, 2007). On the other hand, active protein carbonyl residues, such as alkyl, peroxyl radicals that formed by muscle protein oxidation can be initialized by lipid oxidation, metal ions and other peroxided compounds (Cai et al., 2002). Subsequently, these carbonyls could interact with Maillard reaction via Schiff base and then generate Strecker aldehydes, which are intermediates of imidazoquinolines and imidazoquinoxalines (Estévez, 2011; Soladoye et al., 2015). Researchers also suggested that lipid oxidation could trigger protein oxidation by reacting with heme iron that released from myoglobin (Ganhão et al., 2010; Vuorela et al., 2005). In this work, there was no correlation 
observed between TBARS /protein carbonyl and PAHs ( $p>0.05)$, which indicated that the involvement of lipid and protein oxidation in the formation of PAHs was only at null level. Thus, no linear regression model was fitted. The antioxidants in vegetable oils could not inhibit the formation of PAHs, which was evidenced by null correlation between TEAC and PAHs ( $p>0.05)$.

\section{Conclusions}

Control patties contained the highest amount of HCAs and relatively higher PAHs at $180^{\circ} \mathrm{C}$ and $220^{\circ} \mathrm{C}$. All 3 fat modified patties had significantly lower HCAs, which could be attributed to antioxidants, such as tocopherols and polyphenol compounds existing in the oils. The negative correlation $(r=-0.618, p<0.01)$ between the antioxidant capacity of lipids and the total amount of HCAs could be useful evidence to support this claim. Both lipid and protein oxidation contributed to the formation of HCAs, which were supported by the positive relationship between TBARS/ protein carbonyl values and total HCAs with $r=0.826$ and $0.788(p<0.01)$, respectively. Olive oil and sunflower oil completely prohibited MelQ, whereas grape seed oil could inhibit MelQx, 4, 8-DiMelQx and PhIP. Grape seed oil could achieve the highest inhibitive effect on the formation of HCAs. However, effect of vegetable oils on the formation of PAHs was not consistent, which could be attributed to complexity of oil decomposition and antioxidants in the oils. The involvement of lipid oxidation and protein oxidation in formation of PAHs was limited or at a minimum level. Antioxidants in oils could not reduce the total amount of PAHs effectively. Therefore, it is necessary to explore other methods to reduce PAHs in processed meat. Due to the synergistic effect of antioxidants, it would be interesting to explore replacing pork back fat with a mixture of several types of oils to reach an optimum fatty acids profile, 
754

755

756

757

758

759

760

761

762

763

764

765

766

767

768

769

770

771

772

773

774

775

776

777

778

779

780

781

782

783

784

785

786

787

788

789

790

791

792

instead of replacing pork back fat with one single type of oil. Overall, replacing pork

back fat with vegetable oils in processed meat products could offer healthier meat

products with reduced HCAs without compromising eating quality.

\section{Acknowledgement}

We thank C. Humphrey, C. Busey, M. Puranik and other technicians at University of

Reading for the technical support.

\section{References}

Agostini, F., Bertussi, R. A., Agostini, F., Atti dos Santos, A. C., Rossato, M., \& Vanderlinde, R. (2012). Supercritical Extraction from Vinification Residues: Fatty Acids, $\alpha$-Tocopherol, and Phenolic Compounds in the Oil Seeds from Different Varieties of Grape. The ScientificWorld Journal, 2012, 1-9. doi:10.1100/2012/790486 .

Ahn, J., Grün, I. U., \& Fernando, L. N. (2002). Antioxidant Properties of Natural Plant Extracts Containing Polyphenolic Compounds in Cooked Ground Beef. Food Chemistry and Toxicology, 67, 1364-1369.

Alomirah, H., S., A.-Z., S., A.-H., Zaghloul, S., Sawaya, W., Ahmed, N., \& Kannan, K. (2011). Concentration and dietary exposure to polycyclic aromatic hydrocarbons (PAHs) from grilled and smoked foods. Food Control, 22, 20282035.

AOAC. (2016). Official methods of analysis of AOAC International. Guidelines for Standard Method Performance Requirements: Appendix F. http://www.eoma.aoac.org/app f.pdf Retrieved on 24//05/2017.

Bail, S., Stuebiger, G., Krist, S., Unterweger, H., \& Buchbauer, G. (2008). Characterisation of various grape seed oils by volatile compounds, triacylglycerol composition, total phenols and antioxidant capacity. Food Chemistry, 108(3), 1122-1132.

Balogh, Z., Gray, J. I., Gomaa, E. A., \& Booren, A. M. (2000). Formation and inhibition of heterocyclic aromatic amines in fried ground beef patties. Food and Chemical Toxicology, 38(5), 395-401. doi:http://dx.doi.org/10.1016/S0278-6915(00)00010-7

Botsoglou, E., Govaris, A., Ambrosiadis, I., Fletourisc, D., \& Papageorgioud, G. (2014). Effect of olive leaf (Olea europea L.) extracts on protein and lipid oxidation in cooked pork meat patties enriched with n-3 fatty acids. Journal of the Science of Food and Agriculture, 94, 227-234.

Brown, L. R. (2013). Moving up the food Chain. Retrieved from http://permaculturenews.org/2013/11/27/moving-food-chain/

Cai, W., Gao, Q.-d., Zhu, L., Peppa, M., He, C., \& Vlassara, H. (2002). Oxidative Stress-Inducing Carbonyl Compounds From Common Foods: Novel Mediators of Cellular Dysfunction. Molecular Medicine, 8(7), 337-346. 
Castelo-Branco, V. N., \& Torres, A. G. (2012). Generalized linear model describes determinants of total antioxidant capacity of refined vegetable oils. European Journal of Lipid Science and Technology, 114(3), 332-342.

Chen, B. H., \& Chen, Y. C. (2001). Formation of Polycyclic Aromatic Hydrocarbons in the Smoke from Heated Model Lipids and Food Lipids. Journal of agricultural and food chemistry, 49, 5238-5243.

Chen, B. H., \& Lin, Y. S. (1997). Formation of Polycyclic Aromatic Hydrocarbons during Processing of Duck Meat. Journal of agricultural and food chemistry, 45, 1394-1403.

Cheng, K. W., Chen, F., \& Wang, M. (2007). Inhibitory activities of dietary phenolic compounds on heterocyclic amine formation in both chemical model system and beef patties. Molecular Nutrition \& Food Research, 51(8), 969-976.

Choi, Y.-S., Choi, J.-H., Han, D.-J., Kim, H.-Y., Lee, M.-A., Kim, H.-W., . . . Kim, C.-J. (2010). Optimization of replacing pork back fat with grape seed oil and rice bran fiber for reduced-fat meat emulsion systems. Meat science, 84(1), 212218. doi:http://dx.doi.org/10.1016/j.meatsci.2009.08.048

Crews, C., Hough, P., Godward, J., Brereton, P., Lees, M., Guiet, S., \& Winkelmann, W. (2006). Quantitation of the Main Constituents of Some Authentic GrapeSeed Oils of Different Origin. Journal of agricultural and food chemistry, 54, 6261-6265.

Domínguez, R., Agregán, R., Gonçalves, A., \& Lorenzo, J. M. (2016). Effect of fat replacement by olive oil on the physico-chemical properties, fatty acids, cholesterol and tocopherol content of pâté. Grasas y Aceites, 67(2), 133.

Domínguez, R., Pateiro, M., Agregán, R., \& Lorenzo, J. M. (2017). Effect of the partial replacement of pork backfat by microencapsulated fish oil or mixed fish and olive oil on the quality of frankfurter type sausage. Journal of Food Science and Technology, 54(1), 26-37.

Elmore, J. S., Campo, M. M., Enser, M., \& Mottram, D. S. (2002). Effect of Lipid Composition on Meat-like Model Systems Containing Cysteine, Ribose, and Polyunsaturated Fatty Acids. Journal of agricultural and food chemistry, 50, 1126-1132.

Estévez, M. (2011). Protein carbonyls in meat systems: A review. Meat science, 89(3), 259-279. doi:http://dx.doi.org/10.1016/j.meatsci.2011.04.025

Farhadian, A., Jinap, S., Abas, F., \& Sakar, Z. I. (2010). Determination of polycyclic aromatic hydrocarbons in grilled meat. Food Control, 21, 606-610.

Field, A. (2009). Discovering statistics using SPSS : (and sex and drugs and rock ' $n$ ' roll). 3rd ed. London: Sage.

Frankel, E. N. (1998). Lipid oxidation: Chapter 8 Antioxidatns. Dundee: Oily Press.

Fromberg, A., Højgard, A., \& Duedahl-olesen, L. (2007). Analysis of polycyclic aromatic hydrocarbons in vegetable oils combining gel permeation chromatography with solid-phase extraction clean-up. Food Additives and Contaminants, 24(7), 758-767.

Ganhão, R., Morcuende, D., \& Estévez, M. (2010). Protein oxidation in emulsified cooked burger patties with added fruit extracts: Influence on colour and texture deterioration during chill storage. Meat science, 85(3), 402-409. doi:http://dx.doi.org/10.1016/j.meatsci.2010.02.008

Gibis, M., Kruwinnus, M., \& Weiss, J. (2015). Impact of different pan-frying conditions on the formation of heterocyclic aromatic amines and sensory quality in fried bacon. Food Chemistry, 168, 383-389. doi:http://dx.doi.org/10.1016/j.foodchem.2014.07.074 
Gibis, M., \& Weiss, J. (2012). Antioxidant capacity and inhibitory effect of grape seed and rosemary extract in marinades on the formation of heterocyclic amines in fried beef patties. Food Chemistry, 134, 766-774.

Gibis, M., \& Weiss, J. (2015). Impact of Precursors Creatine, Creatinine, and Glucose on the Formation of Heterocyclic Aromatic Amines in Grilled Patties of Various Animal Species. Journal of Food Science, 80(11), C2430-C2439.

Girard, J. P. (1992). Chapter 2: Cooking. In M.Laroche (Ed.), Technology of Meat and Meat Products. Chichster, England: Ellis Horwood Limited.

Guillén, M., \& Uriarte, P. (2012a). Aldehydes contained in edible oils of a very different nature after prolonged heating at frying temperature: Presence of toxic oxygenated $\alpha, \beta$ unsaturated aldehydes. Food Chemistry, 131(3), 915926. doi:http://dx.doi.org/10.1016/j.foodchem.2011.09.079

Guillén, M. D., \& Uriarte, P. S. (2012b). Study by 1H NMR spectroscopy of the evolution of extra virgin olive oil composition submitted to frying temperature in an industrial fryer for a prolonged period of time. Food Chemistry, 134(1), 162-172. doi: https://doi.org/10.1016/j.foodchem.2012.02.083

Gunstone, F. D. (2002). Vegetable oils in food technology : composition, properties and uses. Oxford Blackwell.

Hasnol, N. D. S., Jinap, S., \& Sanny, M. (2014). Effect of different types of sugars in a marinating formulation on the formation of heterocyclic amines in grilled chicken. Food Chemistry, 145, 514-521.

Horwitz, W., \& Latimer, G. W. (2005). Official methods of analysis of AOAC International. 18th Edition. Gaithersburg AOAC International.

Hui, Y. H. (2001). Chapter 3: Meat colour. In O. Y. a. J. West (Ed.), Meat science and applications. New York: Marcel Dekker.

Hur, S. J., Jin, S. K., \& Kim, I. S. (2008). Effect of extra virgin olive oil substitution for fat on quality of pork patty. Journal of the Science of Food and Agriculture 88, 1231-1237.

Hwang, D. K., \& Ngadi, M. (2002). Kinetics of Heterocyclic Amines Formation in Meat Emulsion at Different Fat Contents. LWT - Food Science and Technology, 35(7), 600-606. doi:http://dx.doi.org/10.1006/fstl.2002.0913

IARC. (1993). Some naturally occurring substances: food items and constituents, heterocyclic aromatic amines and mycotoxins. IARC Monographs on the Evaluation of Carcinogenic Risks to Humans, 56, 165-195.

Ishizaki, A., Saito, K., Hanioka, N., Narimatsu, S., \& Kataoka, H. (2010). Determination of polycyclic aromatic hydrocarbons in food samples by automated on-line in-tube solid-phase micro extraction coupled with highperformance liquid chromatography-fluorescence detection. Journal of Chromatography A, 1217, 5555-5563.

Iwasaki, M., Kataoka, H., Ishihara, J., Takachi, R., Hamada, G. S., Sharma, S., . . . Tsugane, S. (2010). Heterocyclic amines content of meat and fish cooked by Brazilian methods. Journal of Food Composition and Analysis, 23, 61-69.

Jägerstad, M., Skog, K., Arvidsson, P., \& Solyakov, A. (1998). Chemistry, formation and occurrence of genotoxic heterocyclic amines identified in model systems and cooked foods. $Z$ Lebensm Unters Forsch A, 207, 419-427.

Jamali, M. A., Zhang, Y., Teng, H., Li, S., Wang, F., \& Peng, Z. (2016). Inhibitory Effect of Rosa rugosa Tea Extract on the Formation of Heterocyclic Amines in Meat Patties at Different Temperatures. Molecules, 21(2), 173.

Janoszka, B. (2010). Heterocyclic amines and azaarenes in pan-fried meat and its gravy fried without additives and in the presence of onion and garlic. Food 

Chemistry, 120(2), 463-473. doi:http://dx.doi.org/10.1016/j.foodchem.2009.10.039

Janoszka, B. (2011). HPLC-fluorescence analysis of polycyclic aromatic hydrocarbons (PAHs) in pork meat and its gravy fried without additives and in the presence of onion and garlic. Food Chemistry, 126(3), 1344-1353. doi:http://dx.doi.org/10.1016/j.foodchem.2010.11.097

Jinap, S., Mohd-Mokhtar, M. S., Farhadian, A., Hasnol, N. D. S., Jaafar, S. N., \& Hajeb, P. (2013). Effects of varying degrees of doneness on the formation of Heterocyclic Aromatic Amines in chicken and beef satay. Meat science, 94, 202-207.

Johansson, M., Skog, K., \& Jagerstad, M. (1993). Effects of edible oils and fatty acids on the formation of mutagenic heterocyclic amines in a model system. Cardnogenesis, 14(1), 89-94.

Johansson, M.A.E., Fredholm, L., Bjerne, I. \& Jägerstad, M. (1995). Influence of frying fat on the formation of heterocyclic amines in fried beefburgers and pan residues. Food and Chemical Toxicology, 33(12), pp.993-1004.

Kato, T., Harashima, T., Moriya, N., Kikugawa, K., \& Hiramoto, K. (1996). Formation of the mutagenic/carcinogenic imidazoquinoxaline-type heterocyclic amines through the unstable free radical Maillard intermediates and its inhibition by phenolic antioxidants. Carcinogenesis, 17(11), 2469-2476.

Katragadda, H. R., Fullana, A., Sidhu, S., \& Carbonell-Barrachina, Á. A. (2010). Emissions of volatile aldehydes from heated cooking oils. Food Chemistry, 120(1), 59-65. doi:http://dx.doi.org/10.1016/j.foodchem.2009.09.070

Knize, M. G., Dolbeare, F. A., Carroll, K. I., Moore, D. H., \& Felton, J. S. (1994). Effect of cooking time and temperature on the heterocyclic amine content of fried beef patties. Food and Chemical Toxicology, 32(7), 595-603.

Lan, C. M., Kao, T. H., \& Che, B. H. (2004). Effects of heating time and antioxidants on the formation of heterocyclic amines in marinated foods. Journal of Chromatography $B, 802,27-37$.

Liao, G. Z., Wang, G. Y., Xu, X. L., \& Zhou, G. H. (2010). Effect of cooking methods on the formation of heterocyclic aromatic amines in chicken and duck breast. Meat science, 85(1), 149-154.

Liao, G. Z., Xu, X. L., \& Zhou, G. H. (2009). Effects of cooked temperatures and addition of antioxidants on formation of heterocyclic aromatic amines in pork floss. Journal of Food Processing and Preservation, 33(2), 159-175.

Lorenzo, J. M., Munekata, P. E. S., Pateiro, M., Campagnol, P. C. B., \& Domínguez, R. (2016). Healthy Spanish salchichón enriched with encapsulated $n-3$ long chain fatty acids in konjac glucomannan matrix. Food Research International, 89, 289-295.

Lorenzo, J. M., Purriños, L., Bermudez, R., Cobas, N., Figueiredo, M., \& García Fontán, M. C. (2011). Polycyclic aromatic hydrocarbons (PAHs) in two Spanish traditional smoked sausage varieties: "Chorizo gallego" and "Chorizo de cebolla". Meat science, 89(1), 105-109. doi: http://dx.doi.org/10.1016/j.meatsci.2011.03.017

Lorenzo, J. M., Purriños, L., Fontán, M. C. G., \& Franco, D. (2010). Polycyclic aromatic hydrocarbons (PAHs) in two Spanish traditional smoked sausage varieties: "Androlla" and "Botillo". Meat science, 86(3), 660-664. doi: http://dx.doi.org/10.1016/j.meatsci.2010.05.032

Matthäus, B. (2008). Virgin grape seed oil: Is it really a nutritional highlight? European Journal of Lipid Science and Technology, 110, 645-650. 
McAfee, A. J., McSorley, E. M., Cuskelly, G. J., Moss, B. W., Wallace, J. M. W., Bonham, M. P., \& Fearon, A. M. (2010). Red meat consumption: An overview of the risks and benefits. Meat science, 84(1), 1-13. doi:http://dx.doi.org/10.1016/j.meatsci.2009.08.029

McCance, R. A., \& Widdowson, E. M. (2002). McCance and Widdowson's The composition of foods. Section 2.4: Fats and oils (6th ed.). Cambridge, London: The Royal Society of Chemistry, Food Standards Agency.

Messner, C., \& Murkovic, M. (2004). Evaluation of a new model system for studying the formation of heterocyclic amines. Journal of Chromatography B, 802(1), 19-26. doi:http://dx.doi.org/10.1016/j.jchromb.2003.11.015

Morello, M. J., Shahidi, F., \& Ho, C. (2002). Free radicals in food : chemistry, nutrition, and health effects. Chapter 5: Radical Induced Formation of DGlucosone from Amadori Compounds. Washington DC: American Chemical Society.

Nisha, A. R., Dinesh, K. V., Arivudainambi, S., Umer, M., \& Khan, M. S. (2015). Polycyclic aromatic hydrocarbons in processed meats: A toxicological perspective. Research Journal of Chemistry and Environment, 19(6), 72-76.

Nollet, L. M. L. (2012). Chapter 3: Attributes of Muscle Food: Color, Texture, Flavor. In L. M. L. Nollet (Ed.), Handbook of Meat, Poultry and Seafood Quality. Oxford, UK: Blackwell Publishing Ltd.

Oguri, A., Suda, M., Totsuka, Y., Sugimura, T., \& Wakabayashi, K. (1998). Inhibitory effects of antioxidants on formation of heterocyclic amines. Mutation Research, 42, 237-245.

Olsson, V., \& Pickova, J. (2005). The Influence of Production Systems on Meat Quality, with Emphasis on Pork. AMBIO: A Journal of the Human Environment, 34(4), 338-343.

Oz, F., \& Cakmak, I. H. (2016). The effects of conjugated linoleic acid usage in meatball production on the formation of heterocyclic aromatic amines. $L W T$ Food Science and Technology, 65, 1031-1037.

Oz, F., \& Kaya, M. (2010). Effect of Cooking Techniques and Levels on the Formation of Heterocyclic Aromatic Amines in Chicken and Fish. Journal of Animal and Veterinary Advances, 9(8), 1259-1264.

Oz, F., \& Kaya, M. (2011). The inhibitory effect of black pepper on formation of heterocyclic aromatic amines in high-fat meatball. Food Control, 22, 596-600.

Palka, K., \& Daun, H. (1999). Changes in texture, cooking losses, and myofibrillar structure of bovine $\mathrm{M}$. semitendinosus during heating. Meat science, 51(3), 237-243. doi:http://dx.doi.org/10.1016/S0309-1740(98)00119-3

Pearson, A. M., Chen, C., Gray, J. I., \& Aust, S. D. (1992). Mechanism (s) involved in meat mutagen formation and inhibition. Free Radical Biology and Medicine, 13(2), 161-167.

PHE. (2008). Public Health England: Polycyclic Aromatic Hydrocarbons. England. Puangsombat, K., Gadgil, P., Houser, T. A., Hunt, M. C., \& Smith, J. S. (2011). Heterocyclic amine content in commercial ready to eat meat products. Meat Science, 88, 227-233.

Purcaro, G., Moret, S., \& Conte, L. S. (2013). Overview on polycyclic aromatic hydrocarbons: Occurrence, legislation and innovative determination in foods. Talanta, 105, 292-305. doi:http://dx.doi.org/10.1016/j.talanta.2012.10.041

Qiao, M., Fletcher, D., Smith, D., \& Northcutt, J. (2001). The effect of broiler breast meat color on $\mathrm{pH}$, moisture, water-holding capacity, and emulsification capacity. Poultry Science, 80(5), 676-680. 
Rahman, U., Sahar, A., Khan, M. I., \& Nadeem, M. (2014). Production of heterocyclic aromatic amines in meat: Chemistry, health risks and inhibition. A review. LWT - Food Science and Technology, 59, 229-233.

Ramírez-Anaya, J. d. P., Samaniego-Sánchez, C., Castañeda-Saucedo, M. C., Villalón-Mir, M., \& de la Serrana, H. L.-G. (2015). Phenols and the antioxidant capacity of Mediterranean vegetables prepared with extra virgin olive oil using different domestic cooking techniques. Food Chemistry, 188, 430-438. doi:http://dx.doi.org/10.1016/j.foodchem.2015.04.124

Rodr'ıguez-Carpena, J. G., Morcuende, D., \& Est'evez, M. (2011). Partial Replacement of Pork Back-Fat by Vegetable Oils in Burger Patties: Effect on Oxidative Stability and Texture and Color Changes during Cooking and Chilled Storage. Journal of Food Science, 76(7), 1025-1031.

Rodríguez-Carpena, J. G., Morcuende, D., \& Estévez, M. (2012). Avocado, sunflower and olive oils as replacers of pork back-fat in burger patties: Effect on lipid composition, oxidative stability and quality traits. Meat science, 90(1), 106-115. doi:http://dx.doi.org/10.1016/j.meatsci.2011.06.007

Rojas, M. C., \& brewer, M. S. (2007). Effect of Natural Antioxidants on Oxidative Stability of Cooked, Refrigerated Beef and Pork. Journal of Food Science, 72, S282-S288.

Roldán, M., Antequera, T., Martín, A., Mayoral, A. I., \& Ruiz, J. (2013). Effect of different temperature-time combinations on physicochemical, microbiological, textural and structural features of sous-vide cooked lamb loins. Meat science, 93(3), 572-578. doi:http://dx.doi.org/10.1016/j.meatsci.2012.11.014

Roldán, M., Antequera, T., Pérez-Palacios, T., \& Ruiz, J. (2014). Effect of added phosphate and type of cooking method on physico-chemical and sensory features of cooked lamb loins. Meat science, 97(1), 69-75.

Roman, O., Heyd, B., Broyart, B., Castillo, R., \& Maillard, M. (2013). Oxidative reactivity of unsaturated fatty acids from sunflower, high oleic sunflower and rapeseed oils subjected to heat treatment, under controlled conditions. $L W T$ Food Science and Technology, 52, 49-59.

Rombaut, N., Savoire, R., Thomasset, B., Bélliard, T., Castello, J., Van Hecke, É., \& Lanoisellé, J.-L. (2014). Grape seed oil extraction: Interest of supercritical fluid extraction and gas-assisted mechanical extraction for enhancing polyphenol co-extraction in oil. Comptes Rendus Chimie, 17(3), 284-292. doi:http://dx.doi.org/10.1016/j.crci.2013.11.014

Rounds, L., Havens, C. M., Feinstein, Y., Friedman, M., \& Ravishankar, S. (2012). Plant extracts, spices, and essential oils inactivate Escherichia coli O157: H7 and reduce formation of potentially carcinogenic heterocyclic amines in cooked beef patties. Journal of agricultural and food chemistry, 60(14), 37923799.

Sadler, M. J. (2014). Food, Nutrients and Food Ingredients with Authories EU Health Claims (Vol. 1). Cambridge, UK: Woodhead Publishing.

Salmon, C. P., Knize, M. G., \& Felton, J. S. (1997). Effects of Marinating on Heterocyclic Amine Carcinogen Formation in Grilled Chicken. Food and Chemical Toxicology, 35, 433-441.

Sánchez del Pulgar, J., Gázquez, A., \& Ruiz-Carrascal, J. (2012). Physico-chemical, textural and structural characteristics of sous-vide cooked pork cheeks as affected by vacuum, cooking temperature, and cooking time. Meat science, 90(3), 828-835. doi:http://dx.doi.org/10.1016/j.meatsci.2011.11.024 
Singh, L., Varshney, J. G., \& Agarwal, T. (2016). Polycyclic aromatic hydrocarbons' formation and occurrence in processed food. Food Chemistry, 199, 768-781. doi:http://dx.doi.org/10.1016/j.foodchem.2015.12.074

Skog, K. I., Johansson, M. A. E., \& Jaègerstad, M. I. (1998). Carcinogenic Heterocyclic Amines in Model Systems and Cooked Foods: A Review on Formation, Occurrence and Intake. Food and Chemical Toxicology, 36, 879896.

Stevens, J. M., Hamstra, A., Hegeman, T., \& Scharrer, G. (2006). Factors and Parameters that Directly Affect Recovery of Collected Fractions in Preparative HPLC. 24. http://www.gilson.com/Resources/Factors_and_Parameters_that_Directly_Aff ect_Recovery_of_Collected_Fractions_in_Preparative_HPLC.pdf

Soladoye, O. P., Juárez, M. L., Aalhus, J. L., Shānd, P., \& Estévez, M. (2015). Protein Oxidation in Processed Meat: Mechanisms and Potential Implications on Human Health. Comprehensive Reviews in Food Science and Food Safety, 14(2), 106-122.

Tang, S., Sheehan, D., Buckley, D. J., Morrissey, P. A., \& Kerry, J. P. (2001). Antioxidant activity of added tea catechins on lipid oxidation of raw minced red meat, poultry and fish muscle. International Journal of Food Science \& Technology, 36(6), 685-692.

Turesky, R. J. (2010). Heterocyclic Aromatic Amines, Potential human carcinogens. . Advances in molecular toxicology, 4, 37-74.

van den Berg, R., Haenen, G. R. M. M., van den Berg, H., \& Bast, A. (1999). Applicability of an improved Trolox equivalent antioxidant capacity (TEAC) assay for evaluation of antioxidant capacity measurements of mixtures. Food Chemistry, 66(4), 511-517. doi:http://dx.doi.org/10.1016/S03088146(99)00089-8

Vangnai, K., Houser, T. A., Hunt, M. C., \& Smith, J. S. (2014). Effect of enhancement on the formation of heterocyclic amines in cooked pork loins: Preliminary studies. Meat science, 98(2), 88-93. doi:http://dx.doi.org/10.1016/j.meatsci.2014.05.007

Viegas, O., Amaro, L. F., Ferreira, I. M. P. L. V. O., \& Pinho, O. (2012). Inhibitory Effect of Antioxidant-Rich Marinades on the Formation of Heterocyclic Aromatic Amines in Pan-Fried Beef. Journal of Agriculture and Food Chemistry, 60, 6235-6240.

Vitaglione, P., \& Fogliano, V. (2004). Use of antioxidants to minimize the human health risk associated to mutagenic/carcinogenic heterocyclic amines in food. Journal of Chromatography B, 802, 189-199.

Vittadini, E., Rinaldi, M., Chiavaro, E., Barbanti, D., \& Massini, R. (2005). The effect of different convection cooking methods on the instrumental quality and yield of pork Longissimus dorsi. Meat science, 69(4), 749-756. doi:http://dx.doi.org/10.1016/j.meatsci.2004.11.005

Vuorela, S., Salminen, H., Makela, M., Kivikari, R., Karonen, M., \& M.Heinonen. (2005). Effect of Plant Phenolics on Protein and Lipid Oxidation in Cooked Pork Meat Patties. Journal of agricultural and food chemistry, 53, 8492-8497.

Vural, H., \& Javidipour, I. (2002). Replacement of beef fat in Frankfurters by interesterified palm, cottonseed and olive oils. European Food Research and Technology, 214(6), 465-468. 
Wong, D., Cheng, K., \& Wang, M. (2012). Inhibition of heterocyclic amine formation by water-soluble vitamins in Maillard reaction model systems and beef patties. Food Chemistry, 133, 760-766.

Wong, D., Hu, X., Tao, N., Wang, X., \& Wang, M. (2015). Effect and mechanism of pyridoxamine on the lipid peroxidation and stability of polyunsaturated fatty acids in beef patties. Journal of the Science of Food and Agriculture. doi:10.1002/jsfa.7522

Wretling, S., Eriksson, A., Eskhult, G. A., \& Larsson, B. (2010). Polycyclic aromatic hydrocarbons (PAHs) in Swedish smoked meat and fish. Journal of Food Composition and Analysis, 23, 264-272.

Yao, Y., Peng, Z., Shao, B., Wan, K., Wang, F., Zhang, Y., . . Hui, T. (2013). Effects of frying and boiling on the formation of heterocyclic amines in braised chicken. Poultry Science, 92(11), 3017-3025.

Youssef, M. K., \& Barbut, S. (2009). Effects of protein level and fat/oil on emulsion stability, texture, microstructure and color of meat batters. Meat science, 82(2), 228-233. doi:http://dx.doi.org/10.1016/j.meatsci.2009.01.015

Zamora, R., Alcón, E. and Hidalgo, F.J. (2012). Effect of lipid oxidation products on the formation of 2-amino-1-methyl-6-phenylimidazo [4, 5-b] pyridine (PhIP) in model systems. Food chemistry, 135(4), 2569-2574.

Zamora, R., \& Hidalgo, F. J. (2007). Coordinate Contribution of Lipid Oxidation and Maillard Reaction to the Nonenzymatic Food Browning. Critical Reviews in Food Science and Nutrition, 45(1), 49-59.

Zamora, R., \& Hidalg, F. J. (2015). 2-Amino-1-methyl-6-phenylimidazo[4,5-b]pyridine (PhIP) formation and fate: an example ofthe coordinate contribution of lipid oxidation and Maillard reaction to the production and elimination of processing-related food toxicants. Royal Society of Chemistry, 5, 9709-9721.

Zhang, Y., Yu, C., Mei, J., \& Wang, S. (2013). Formation and mitigation of heterocyclic aromatic amines in fried pork. Food Additives \& Contaminants: Part A, 30(9), 1501-1507.

Zhu, W., Cromie, M. M., Cai, Q., Lv, T., Singh, K., \& Gao, W. (2014). Curcumin and Vitamin E Protect against Adverse Effects of Benzo[a]pyrene in Lung Epithelial Cells. PLoS ONE 9(3), e92992. . doi:doi:10.1371/journal.pone.0092992 
Table 1: Formulation of control and fat reduced pork patties

Ingredients in recipe represent as $\mathrm{g} / 1 \mathrm{~kg}$

Treatment

Control, pork back fat (C patties)

Fat replaced with Sunflower oil (S patties)

Fat replaced with Olive oil (O patties)

Fat replaced with Grape seed oil (G patties)

\section{Lean pork leg}

700

700

700

700

1128

1129

1130

1131

1132

1133

1134 
Table 2: Proximate composition and $\mathrm{pH}$ values of 4 types of patties cooked at $180^{\circ} \mathrm{C}$ and $220^{\circ} \mathrm{C}$ a,b.

\begin{tabular}{|c|c|c|c|c|c|c|}
\hline Treatment & Cooking & Moisture (\%) & Cooking loss & Fat (\%) & Protein (\%) & $\mathrm{pH}$ \\
\hline \multirow[t]{2}{*}{ Control } & $\begin{array}{l}\text { temperature }\left({ }^{\circ} \mathrm{C}\right) \\
180\end{array}$ & $69.15 \pm 0.30^{d}$ & $20.51 \pm 1.59^{a}$ & $10.01 \pm 0.85^{a}$ & $15.19 \pm 1.56^{a}$ & $5.99 \pm 0.01^{a}$ \\
\hline & 220 & $63.58 \pm 0.60^{a}$ & $24.75 \pm 1.24^{d}$ & $9.98 \pm 1.05^{a}$ & $15.03 \pm 1.69^{a}$ & $5.85 \pm 0.02^{b}$ \\
\hline \multirow[t]{2}{*}{ Olive oil } & 180 & $65.91 \pm 0.16^{b}$ & $20.30 \pm 0.60^{a}$ & $9.62 \pm 1.21^{a}$ & $15.21 \pm 1.98^{a}$ & $5.85 \pm 0.02^{b}$ \\
\hline & 220 & $63.36 \pm 0.37^{a}$ & $23.21 \pm 0.84^{\mathrm{bcd}}$ & $9.49 \pm 1.25^{\mathrm{a}}$ & $15.09 \pm 1.37^{a}$ & $5.86 \pm 0.01^{b}$ \\
\hline \multirow[t]{2}{*}{ Sunflower oil } & 180 & $66.34 \pm 0.63^{b}$ & $22.54 \pm 0.29 \mathrm{bc}$ & $9.68 \pm 1.17^{a}$ & $15.28 \pm 1.59^{a}$ & $5.88 \pm 0.01^{b}$ \\
\hline & 220 & $63.49 \pm 0.15^{a}$ & $24.23 \pm 0.76^{\mathrm{cd}}$ & $9.70 \pm 1.05^{\mathrm{a}}$ & $15.17 \pm 1.94^{a}$ & $5.87 \pm 0.02^{b}$ \\
\hline \multirow[t]{2}{*}{ Grapeseed oil } & 180 & $67.53 \pm 0.26^{c}$ & $21.88 \pm 0.31^{a b}$ & $9.76 \pm 1.14^{a}$ & $15.34 \pm 1.32^{a}$ & $5.87 \pm 0.02^{b}$ \\
\hline & 220 & $65.90 \pm 0.09^{b}$ & $9^{d}$ & $9.68 \pm 1.32^{\mathrm{a}}$ & $15.17 \pm 1.46^{a}$ & $5.87 \pm 0.01^{b}$ \\
\hline \multicolumn{2}{|c|}{ p-value (Type of oil) } & 0.21 & 0.43 & 0.74 & 0.54 & 0.065 \\
\hline \multicolumn{2}{|c|}{ p-value (Temperature) } & $<0.01$ & $<0.01$ & 0.33 & 0.28 & 0.16 \\
\hline \multicolumn{2}{|c|}{$\begin{array}{l}p \text {-value (Interaction between oil }{ }^{*} \\
\text { temperature) }\end{array}$} & 0.18 & $<0.01$ & 0.49 & 0.15 & 0.16 \\
\hline
\end{tabular}


1138 Table 3: Texture parameters (hardness, cohesiveness and chewiness) and colour parameters (lightness $L^{*}$, redness $a^{*}$ and

1139 yellowness $b^{*}$ ) in 4 types of patties cooked at $180^{\circ} \mathrm{C}$ and $220^{\circ} \mathrm{C}$ a,b

\begin{tabular}{|c|c|c|c|c|c|c|c|c|}
\hline Treatment & $\begin{array}{l}\text { Cooking } \\
\text { temperat } \\
\text { ure }\left({ }^{\circ} \mathrm{C}\right)\end{array}$ & $\begin{array}{l}\text { Hardness } \\
(\mathrm{N})\end{array}$ & $\begin{array}{c}\text { Cohesivene } \\
\text { ss }\end{array}$ & $\begin{array}{c}\text { Chewiness } \\
\text { (N.s) }\end{array}$ & Springiness & $L^{*}$ & $a^{*}$ & $b^{*}$ \\
\hline \multirow[t]{2}{*}{ Control } & 180 & $20.14 \pm 2.81^{a}$ & $0.34 \pm 0.02^{a b}$ & $4.06 \pm 0.77^{a b}$ & $0.71 \pm 0.03^{a}$ & $70.71 \pm 0.08^{b c}$ & $2.30 \pm 0.11^{\mathrm{c}}$ & $16.98 \pm 0.80^{\mathrm{abc}}$ \\
\hline & 220 & $26.65 \pm 3.15^{\mathrm{b}}$ & $0.37 \pm 0.01^{d}$ & $5.92 \pm 0.77^{c}$ & $0.77 \pm 0.04^{a}$ & $65.80 \pm 1.82^{a}$ & $1.46 \pm 0.22^{\mathrm{ab}}$ & $18.73 \pm 1.15^{c}$ \\
\hline \multirow[t]{2}{*}{ Olive oil } & 180 & $18.02 \pm 3.58^{a}$ & $0.34 \pm 0.01^{a}$ & $3.94 \pm 0.41^{a}$ & $0.72 \pm 0.04^{\mathrm{a}}$ & $69.80 \pm 1.76^{b c}$ & $2.82 \pm 0.08^{d}$ & $16.23 \pm 0.71^{\mathrm{ab}}$ \\
\hline & 220 & $21.75 \pm 0.37^{a}$ & $0.38 \pm 0.01^{d}$ & $5.35 \pm 0.41^{b c}$ & $0.75 \pm 0.02^{a}$ & $65.33 \pm 3.69^{a}$ & $1.18 \pm 0.02^{\mathrm{a}}$ & $17.44 \pm 1.90^{\mathrm{bc}}$ \\
\hline \multirow{2}{*}{$\begin{array}{l}\text { Sunflower } \\
\text { oil }\end{array}$} & 180 & $17.98 \pm 2.45^{a}$ & $0.35 \pm 0.01 \mathrm{abc}$ & $3.96 \pm 0.35^{a}$ & $0.73 \pm 0.05^{a}$ & $70.10 \pm 0.57^{b c}$ & $2.86 \pm 0.13^{d}$ & $15.41 \pm 0.73^{a}$ \\
\hline & 220 & $19.40 \pm 2.81^{a}$ & $0.38 \pm 0.02^{d}$ & $4.34 \pm 0.99 a b$ & $0.74 \pm 0.03^{a}$ & $65.97 \pm 2.05^{a}$ & $1.43 \pm 0.22^{\mathrm{ab}}$ & $17.59 \pm 0.45^{b c}$ \\
\hline \multirow{2}{*}{$\begin{array}{l}\text { Grape } \\
\text { seed oil }\end{array}$} & 180 & $17.86 \pm 1.12^{a}$ & $0.37 \pm 0.01^{\mathrm{cd}}$ & $4.11 \pm 0.30^{\mathrm{ab}}$ & $0.77 \pm 0.01^{a}$ & $71.41 \pm 1.74^{c}$ & $3.24 \pm 0.37^{d}$ & $17.03 \pm 0.38 \mathrm{abc}$ \\
\hline & 220 & $21.55 \pm 2.37^{a}$ & $0.36 \pm 0.01^{b c}$ & $5.22 \pm 1.02^{\mathrm{abc}}$ & $0.77 \pm 0.04^{a}$ & $68.15 \pm 0.47^{a b}$ & $1.66 \pm 0.43^{b}$ & $18.47 \pm 0.15^{c}$ \\
\hline \multicolumn{2}{|c|}{ p-value (Type of oil) } & 0.10 & 0.87 & 0.50 & 0.341 & 0.062 & 0.54 & 0.65 \\
\hline \multicolumn{2}{|c|}{ p-value (Temperature) } & 0.05 & 0.001 & 0.001 & 0.085 & 0.05 & 0.005 & 0.05 \\
\hline \multicolumn{2}{|c|}{$\begin{array}{l}\text { p-value (Interaction } \\
\text { between } \\
\text { oiltemperature) }\end{array}$} & 0.41 & & 0.33 & 0.36 & 0.083 & 0.84 & 0.04 \\
\hline
\end{tabular}

1140 a Results with different letters in the same column are significantly different at the level $p<0.05$.

1141 b Values represented as the Mean $\pm S D, n=3$. 
1142 Table 4: Heterocyclic amines in cooked pork patties with partial replacement of fat by vegetable oils at $180^{\circ} \mathrm{C}$ and $220^{\circ} \mathrm{C}$ a,b,c

\begin{tabular}{|c|c|c|c|c|c|c|c|c|}
\hline Treatment & $\begin{array}{l}\text { Cooking } \\
\text { temperature }\end{array}$ & $\mathrm{IQ}(\mathrm{ng} / \mathrm{g})$ & MelQ (ng/g) & $\begin{array}{l}\text { MelQx } \\
(\mathrm{ng} / \mathrm{g})\end{array}$ & $\begin{array}{l}\text { 4,8-DiMelQx } \\
\text { (ng/g) }\end{array}$ & PhIP (ng/g) & Total (ng/g) & $\begin{array}{l}\text { Inhibitory } \\
\text { efficiency }\end{array}$ \\
\hline \multirow[t]{2}{*}{ Control } & 180 & $\mathrm{Nd}$ & $18.26 \pm 14.46^{a}$ & $8.34 \pm 1.78^{a b}$ & $25.66 \pm 1.51^{b}$ & $11.43 \pm 6.33^{a}$ & $67.56 \pm 17.29^{c}$ & $\mathrm{~N} / \mathrm{a}$ \\
\hline & 220 & $3.88 \pm 3.50^{a}$ & $59.70 \pm 0.98^{b}$ & $13.45 \pm 7.43^{b}$ & $43.37 \pm 15.67^{c}$ & $24.07 \pm 1.99^{b}$ & $140.57 \pm 22.03^{d}$ & $\mathrm{~N} / \mathrm{a}$ \\
\hline \multirow[t]{2}{*}{ Olive oil } & 180 & $0.58 \pm 0.01^{b}$ & $\mathrm{Nd}$ & $3.50 \pm 0.68^{a}$ & & $\mathrm{Nd}$ & $4.11 \pm 0.87^{a}$ & $93.90 \%$ \\
\hline & 220 & $1.30 \pm 0.42^{b}$ & $\mathrm{Nd}$ & $2.52 \pm 0.36^{a}$ & $1.31 \pm 0.22^{a}$ & $14.78 \pm 1.49^{a}$ & $20.03 \pm 2.25^{b}$ & $85.75 \%$ \\
\hline \multirow{2}{*}{$\begin{array}{l}\text { Sunflower } \\
\text { oil }\end{array}$} & 180 & $\mathrm{Nd}$ & $\mathrm{Nd}$ & $4.32 \pm 0.50^{a}$ & $1.02 \pm 0.50^{a}$ & $\mathrm{Nd}$ & $5.98 \pm 1.10^{a}$ & $91.15 \%$ \\
\hline & 220 & $0.64 \pm 0.16^{b}$ & $\mathrm{Nd}$ & $4.31 \pm 0.55^{a}$ & $5.12 \pm 0.35^{\mathrm{a}}$ & $22.70 \pm 1.95^{b}$ & $23.88 \pm 2.44^{b}$ & $83.01 \%$ \\
\hline \multirow{2}{*}{$\begin{array}{l}\text { Grape } \\
\text { seed oil }\end{array}$} & 180 & $\mathrm{Nd}$ & $\mathrm{Nd}$ & $\mathrm{Nd}$ & $\mathrm{Nd}$ & $\mathrm{Nd}$ & $\mathrm{Nd}$ & $100 \%$ \\
\hline & 220 & $0.59 \pm 0.04^{b}$ & $1.31 \pm 0.06^{c}$ & & $\mathrm{Nd}$ & $\mathrm{Nd}$ & $1.90 \pm 0.04^{a}$ & $98.64 \%$ \\
\hline \multicolumn{2}{|c|}{ p-value (Type of oil) } & 0.12 & $<0.01$ & $<0.01$ & $<0.01$ & $<0.01$ & $<0.01$ & - \\
\hline \multicolumn{2}{|c|}{ p-value (Temperature) } & 0.037 & $<0.01$ & 0.37 & 0.039 & $<0.01$ & $<0.01$ & - \\
\hline \multicolumn{2}{|c|}{$\begin{array}{l}\text { p-value (Interaction } \\
\text { between oil }{ }^{\star} \text { temperature) }\end{array}$} & 0.040 & & 0.24 & 0.035 & $<0.01$ & $<0.01$ & - \\
\hline
\end{tabular}

$1143 \quad{ }^{a}$ Results with different letters in the same column are significantly different at the level $p<0.05$.

1144 b Values represented as the Mean \pm SD, $n=3$.

1145 c Nd: Not Detected. 
Table 5: Polycyclic aromatic hydrocarbons in in cooked pork patties with partial replacement of fat by vegetable oils at $180^{\circ} \mathrm{C}$ and $1148220^{\circ} \mathrm{C}$ a,b

\begin{tabular}{|c|c|c|c|c|c|}
\hline Treatment & $\begin{array}{c}\text { Cooking } \\
\text { temperature }\left({ }^{\circ} \mathrm{C}\right)\end{array}$ & $\mathrm{BaA}(\mathrm{ng} / \mathrm{g})$ & $\mathrm{BaP}(\mathrm{ng} / \mathrm{g})$ & Total PAHs (ng/g) & $\begin{array}{l}\text { Inhibitory } \\
\text { efficiency }\end{array}$ \\
\hline \multirow[t]{2}{*}{ Control } & 180 & $0.15 \pm 0.01^{a}$ & $2.44 \pm 0.37^{c}$ & $2.58 \pm 0.36^{c}$ & $\mathrm{~N} / \mathrm{a}$ \\
\hline & 220 & $0.21 \pm 0.03^{b}$ & $3.08 \pm 0.06^{d}$ & $3.28 \pm 0.07^{d}$ & $\mathrm{~N} / \mathrm{a}$ \\
\hline \multirow[t]{2}{*}{ Olive oil } & 180 & $0.15 \pm 0.02^{a}$ & $2.24 \pm 0.40^{b c}$ & $2.38 \pm 0.40^{\mathrm{bc}}$ & $7.75 \%$ \\
\hline & 220 & $0.15 \pm 0.01^{a}$ & $1.44 \pm 0.27^{a}$ & $1.59 \pm 0.26^{a}$ & $51.52 \%$ \\
\hline \multirow[t]{2}{*}{ Sunflower oil } & 180 & $0.14 \pm 0.01^{a}$ & $1.88 \pm 0.17^{a b}$ & $2.02 \pm 0.16^{\mathrm{ab}}$ & $21.71 \%$ \\
\hline & 220 & $0.31 \pm 0.02^{c}$ & $3.53 \pm 0.20^{\mathrm{e}}$ & $3.84 \pm 0.21^{\mathrm{e}}$ & $-17.07 \%$ \\
\hline \multirow[t]{2}{*}{ Grape seed oil } & 180 & $0.18 \pm 0.01^{a b}$ & $3.29 \pm 0.15^{d}$ & $3.46 \pm 0.16^{d}$ & $-34.11 \%$ \\
\hline & 220 & $0.18 \pm 0.05^{\circ}$ & $2.51 \pm 0.07^{c}$ & $2.71 \pm 0.07^{c}$ & $17.38 \%$ \\
\hline \multicolumn{2}{|c|}{ p-value (Type of oil) } & $<0.01$ & $<0.01$ & 0.031 & - \\
\hline \multicolumn{2}{|c|}{ p-value (Temperature) } & 0.1 & 0.076 & 0.43 & - \\
\hline \multicolumn{2}{|c|}{$\begin{array}{l}\text { p-value (Interaction between oil* } \\
\text { temperature) }\end{array}$} & & $<0.01$ & $<0.01$ & - \\
\hline
\end{tabular}

${ }^{a}$ Results with different letters in the same column are significantly different at the level $p<0.05$.

b Values represented as the Mean $\pm S D, n=3$. 
Table 6: Pearson correlation coefficient $(p)$ between the level of total HCAs/PAHs (ng/g) and TBARS, protein carbonyl and TEAC

\begin{tabular}{llll}
\hline & TEAC & HCAs & PAHS \\
TBARS & $-0.764^{* *}$ & $0.826^{* *}$ & -0.154 \\
Protein carbonyl & $-0.606^{* *}$ & $0.778^{* *}$ & 0.019 \\
TEAC & - & $-0.618^{* *}$ & 0.301 \\
\hline ** Significant level 0.01 & & &
\end{tabular}


Figure 1: Trolox Equivalent Antioxidant capacity (umol Trolox/100g) of pork backfat and 3 vegetable oils.

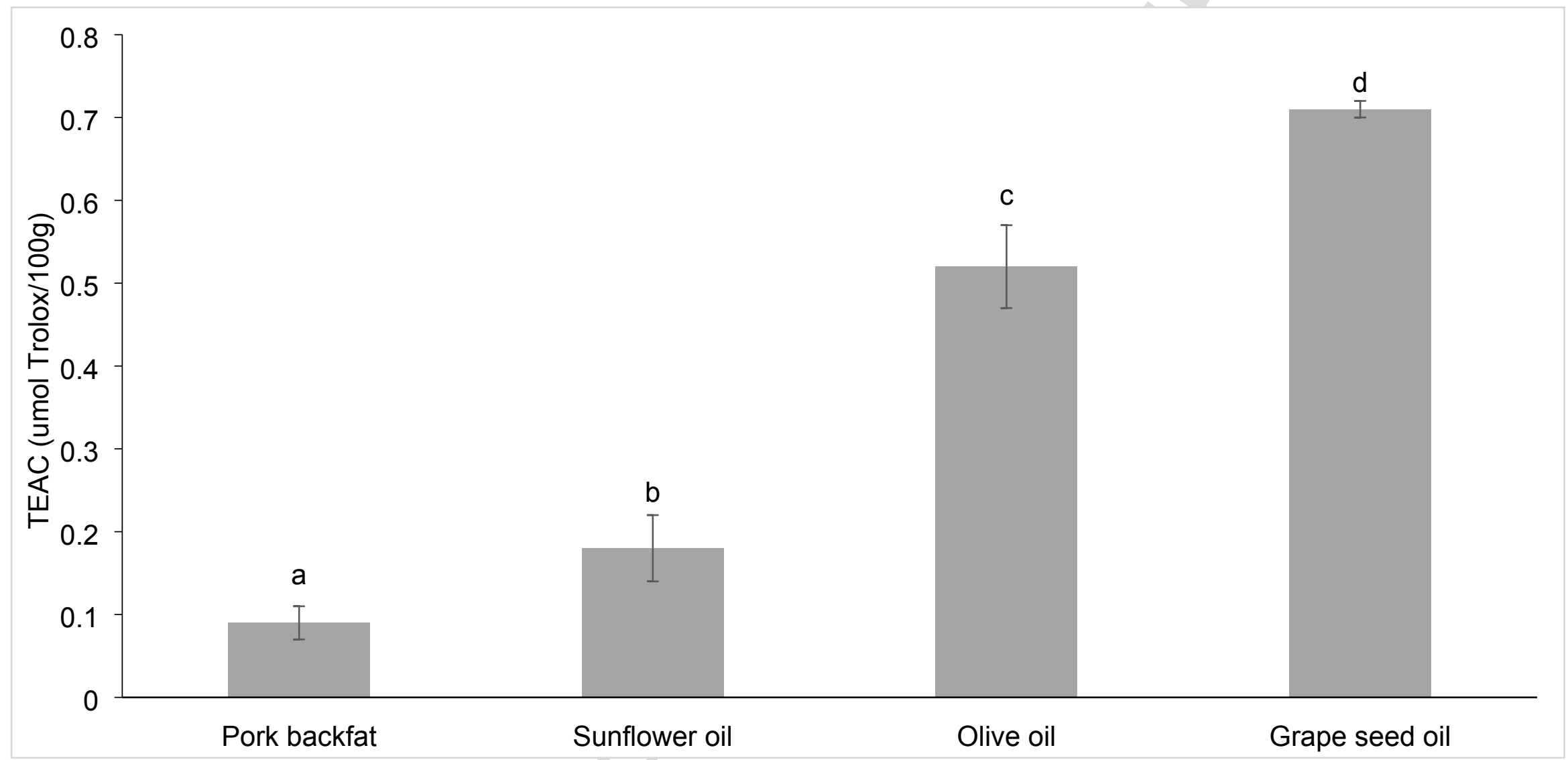

Results with different letters are significantly different at the level $p<0.05$. 
Figure 2: TBARS values in pork patties cooked at $180^{\circ} \mathrm{C}$ and $220^{\circ} \mathrm{C}$.

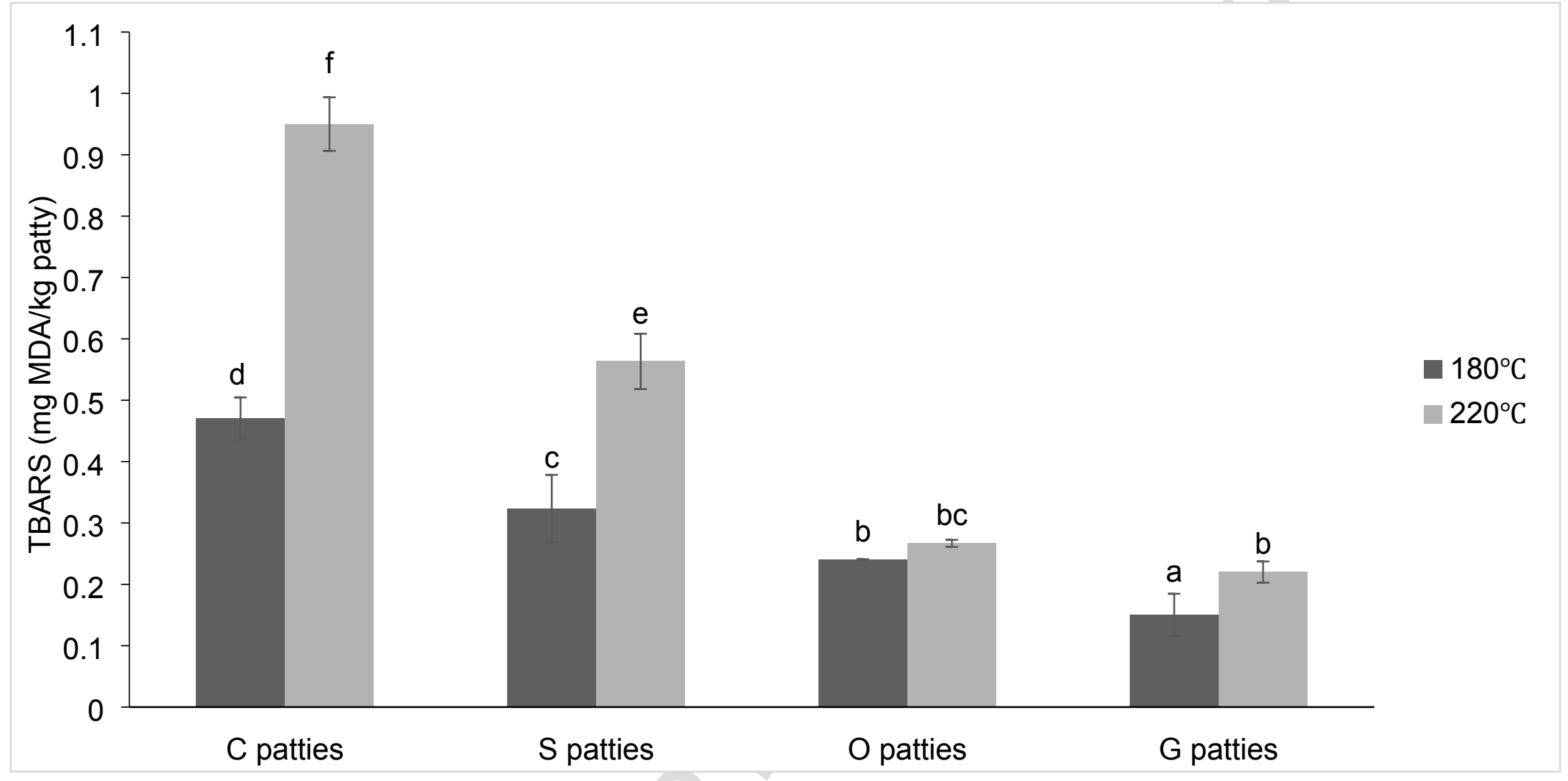

Results with different letters are significantly different at the level $p<0.05$. 
Figure 3: Protein carbonyl values in pork patties cooked at $180^{\circ} \mathrm{C}$ and $220^{\circ} \mathrm{C}$.

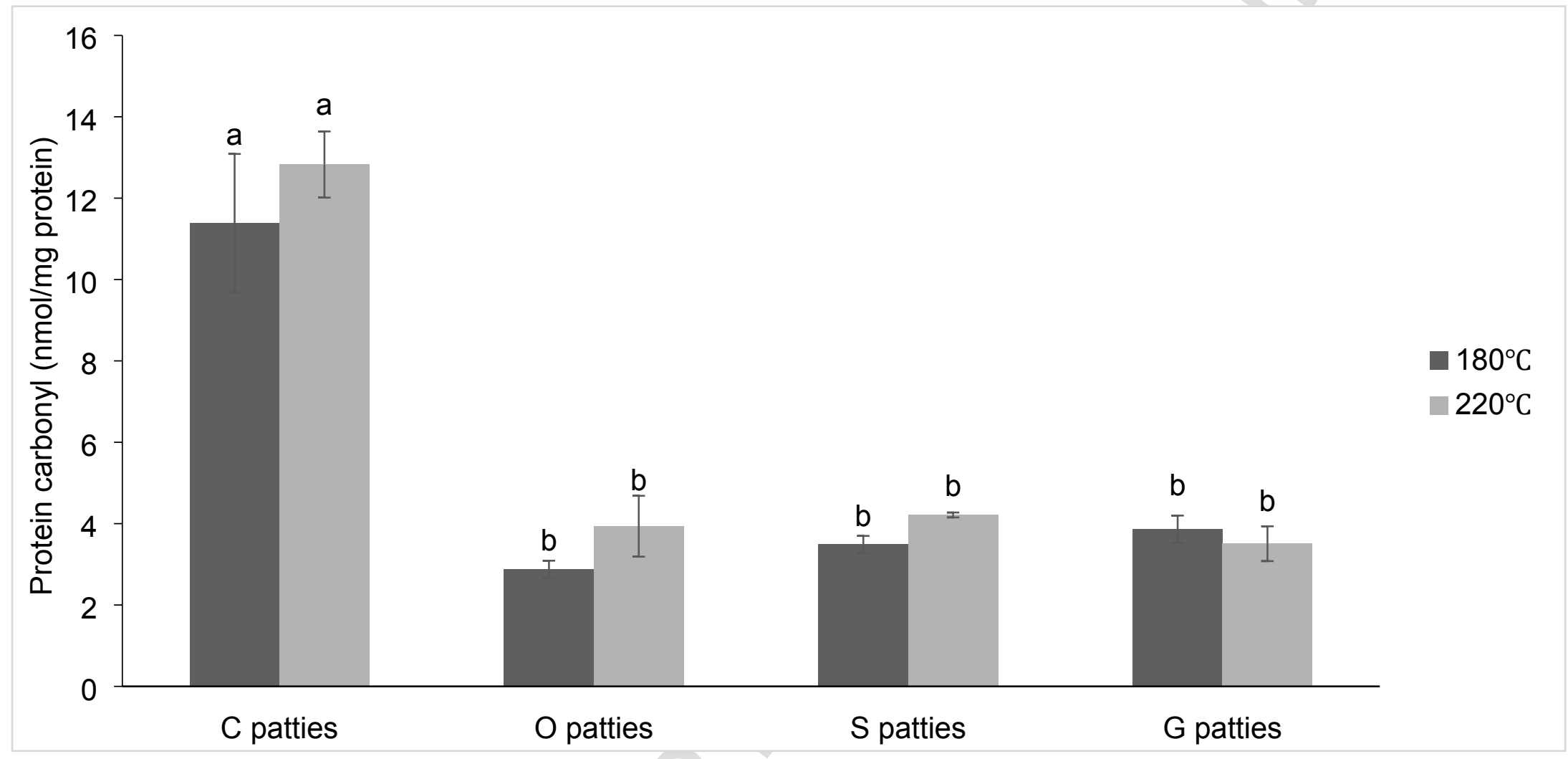

Results with different letters are significantly different at the level $p<0.05$ 
- Antioxidants in these oils could inhibit the formation of HCAs

- Grape seed oil achieved the highest inhibition capacity compared with sunflower oil and olive oil

- Lipid oxidation plays key role in the formation of HCAs

- Cooking temperature did not affect the total PAHs in pork patties 